\title{
Due Diligence in International Environmental Law and International Human Rights Law: A Comparative Legal Study of the Nationally Determined Contributions under the Paris Agreement and Positive Obligations under the European Convention on Human Rights
}

\section{Medes Malaihollo ${ }^{1}$}

Accepted: 7 April 2021 / Published online: 28 April 2021

(c) The Author(s) 2021

\begin{abstract}
Due diligence is a frequently employed notion in international law, yet much is still to be explored about this concept. This article aims to contribute to an understanding of due diligence obligations in international law, which is useful as it can form the basis for a further clarification of corresponding legal rights of subjects of international law. With this purpose in mind, this article initiates the construction of a working model of due diligence in international law by exploring this notion from two perspectives: an accountability perspective and a regulatory perspective. Subsequently, this article will use this model to compare the operation of due diligence obligations in two branches of international law: international environmental law and international human rights law. In doing so, it will become clear that due diligence contains two core elements: 'reasonableness' and 'good faith'. Moreover, it will become apparent that the operation of due diligence obligations in these two branches has implications for systemic issues in international law. Further research on the operation of due diligence obligations in other branches of international law is therefore recommended.
\end{abstract}

Keywords Due diligence · International human rights law · Positive obligations · International environmental law $\cdot$ Nationally determined contributions

Medes Malaihollo a.malaihollo@rug.nl

1 International Law, University of Groningen, Groningen, The Netherlands 


\section{Introduction}

On 20 December 2019, the Dutch Supreme Court decided on a landmark climate change case: the Urgenda case. ${ }^{1}$ In its judgement, the Court declared that the European Convention on Human Rights and Fundamental Freedoms (ECHR) ${ }^{2}$ imposes a positive obligation on the Netherlands. This obligation entails that the state needs to take appropriate measures for the prevention of climate change. In this context, the Court referred to the United Nations climate change regime ${ }^{3}$ and the commitment of Annex I state parties to the aim of reducing greenhouse gas emissions by $25-40 \%$ by $2020 .{ }^{4}$ Such obligations, as further developed in the Paris Agreement under the United Nations Framework Convention on Climate Change (Paris Agreement), are known as due diligence obligations. Remarkably, the Dutch Supreme Court considered that positive obligations under Articles 2 (the right to life) and 8 (the right to respect for one's private life, family life and home) ECHR were the basis for taking all appropriate measures to implement reduction commitments to prevent climate change. ${ }^{5}$ The Court, however, did not elaborate on the question whether the concept of due diligence in international environmental law and the concept of positive obligation in international human rights law are the same or different. More in general, recent studies point out that much is still to be explored when it comes to the normative content of due diligence and its systemic relation to various norms in international law. ${ }^{6}$

This article aims to contribute to the understanding of due diligence in international law. Most academics examine this notion as a technique to allocate

\footnotetext{
${ }^{1}$ Hoge Raad (Supreme Court) 20 December 2019, State of the Netherlands v. Urgenda Foundation, ECLI:NL:HR:2019:2007.

${ }^{2}$ Convention for the Protection of Human Rights and Fundamental Freedoms (ECHR), 3 September 1953, 213 UNTS 222.

${ }^{3}$ The current climate change regime includes several international legal instruments. Core instruments of this regime include the United Nations Framework Convention on Climate Change, the Kyoto Protocol and the Paris Agreement; United Nations Framework Convention on Climate Change (1992 UNFCCC), 21 March 1994, 1771 UNTS 107; Kyoto Protocol to the United Nations Framework Convention on Climate Change (Kyoto Protocol), 16 February 2005, 2303 UNTS 162; Paris Agreement under the United Nations Framework Convention on Climate Change (Paris Agreement), 4 November 2016, 55 ILM 743; also part of the climate change regime are several climate conferences of the Conference of Parties. Important reports include Conference of Parties, Report of the Conference of the Parties, Third Session, 1-11 December 1997, FCCC/CP/2012/8; Conference of Parties, Report of the Conference of the Parties, Thirteenth Session, 3-15 December 2007, FCCC/CP/2007/6/Add.1; Conference of Parties, Report of the Conference of the Parties, Fifteenth Session, 7-19 December 2009, FCCC/CP/2009/11/ Add.1; Conference of Parties, Report of the Conference of the Parties, Sixteenth Session, 29 November-10 December 2010, FCCC/CP/2010/7/Add.1; Conference of Parties, Report of the Conference of the Parties, Eighteenth Session, 26 November-8 December 2012, FCCC/CP/2012/8; Conference of Parties, Report of the Conference of the Parties, Twenty-First Session, 30 November-13 December 2015, FCCC/ CP/2015/10/Add.1.

${ }^{4}$ Urgenda (n. 1), paras. 2.1 and 7.1.

${ }^{5}$ Ibid., paras. 5.2.1-5.3.3 and 5.8.

${ }^{6}$ International Law Association Study Group on Due Diligence in International Law, Second Report, 12 July 2016, https://www.ila-hq.org/index.php/study-groups?study-groupsID=63, p. 47; Peters et al. (2020), p. 1.
} 
accountability in the context of risk management ${ }^{7}$ or in the context of primary and secondary rules in international law. ${ }^{8}$ However, such perspectives relate to only one side of the coin. In international law, due diligence obligations are also used as a regulatory technique where the norm addressee enjoys a broad discretion so as to attain regulatory goals. Due diligence obligations, after all, do not prescribe a particular measure that has to be taken. The norm addressee only has to undertake its best efforts, leading to further law-making and decision-making by the norm addressee. Such regulatory understanding of due diligence obligations, remarkably, remains unexplored in legal literature. ${ }^{9}$ This being said, due diligence obligations arguably operate in two paradigms: an accountability paradigm and a regulation paradigm. Since such a distinction has not yet been examined in greater detail, this article will explore these two paradigms to construct a working model of due diligence in international law. This working model will then form the basis for a comparative legal study of the operation of due diligence obligations under the Paris Agreement and positive obligations under the ECHR. In the end, the findings of this study can be used to further clarify the meaning of this familiar stranger in international law ${ }^{10}$ and to explain corresponding legal rights of subjects of international law. ${ }^{11}$

The structure of this article is as follows. Section 2 will first discuss a particular due diligence obligation that is vital for contemporary climate change mitigation, namely the obligation to take precautionary measures to prevent environmental harm or the risk thereof. This is also known as the precautionary principle. Section 3, subsequently, will analyse the two paradigms of due diligence obligations. This will be illustrated with the help of the precautionary principle. By doing so, a working model of due diligence obligations can be constructed, forming the theoretical framework for the comparative legal study in this article. Section 4 will compare the operation of due diligence obligations related to the nationally determined contributions (NDCs) under the Paris Agreement with the operation of positive obligations under Article 8 ECHR. It will use the theoretical framework as constructed in Sect. 3 to identify similarities and differences. Finally, Sect. 5 will reflect on these findings: due diligence remains a familiar stranger in international law, while at the same time its rise is of systemic importance to many areas of international law.

\footnotetext{
${ }^{7}$ See for example Kulesza (2016); Barnidge Jr. (2008); Schmitt (2015).

${ }^{8}$ See for instance Aust and Feihle (2020).

${ }^{9}$ Except for Krieger and Peters, who have also identified due diligence obligations as having a regulatory function in international law; Krieger and Peters (2020), pp. 351 and 371-372.

${ }^{10}$ For the qualification of due diligence being a 'familiar stranger in international law', see also Peters et al. (2020), p. 1.

${ }^{11}$ According to Krieger and Peters, due diligence even has a significant impact on a structural change to the international legal order; Krieger and Peters (2020).
} 


\section{The Precautionary Principle: A Due Diligence Obligation}

Due diligence is a frequently employed concept in international law. ${ }^{12}$ However, it has been interpreted and applied differently in international law. ${ }^{13}$ For example, the second report on due diligence by the International Law Association (ILA) refers to due diligence as a broad principle of international law, but also as specific obligations in several branches of international law. ${ }^{14}$ Barnidge, however, refers to due diligence as a 'well-established principle of international law' of which its interpretation depends on the responsibility of a state for non-state actors within its territory. ${ }^{15}$ In contrast, Schmitt asserts that due diligence has a broader scope as it is not limited to only non-state actors, but concerns the obligation of a state to ensure acts within the territory under its control are not used to the detriment of other states. ${ }^{16}$ Others, like Pisillo-Mazzeschi and Kulesza, rather refer to due diligence in the context of general accountability. ${ }^{17}$

Although the notion of due diligence has been given different meanings, it has evolved most notably in international environmental law since the second half of the twentieth century. ${ }^{18}$ With that in mind, due diligence concerns a key element in this branch of international law, especially when it comes to preventing transboundary environmental harm to other states and protecting the environment in general. States, in that way, have duties of care. Legal doctrine ${ }^{19}$ and case law ${ }^{20}$ predominantly refer to such duties as 'obligations of conduct'. An example is the obligation of states to take precautionary measures that can reasonably be expected from the state to prevent environmental harm. This is also known as the precautionary principle. $^{21}$

\footnotetext{
12 Longobardo (2019), p. 47.

13 Peters et al. (2020), pp. 8-9.

14 Second Report (n. 6), pp. 12 and 47.

15 Barnidge Jr. (2006), pp. 81-82; Barnidge Jr. (2008), p. 69.

16 Schmitt (2015), p. 69.

17 Pisillo-Mazzeschi (1992); Kulesza (2016).

18 ILA Study Group on Due Diligence in International Law, First Report, 7 March 2014, https://www. ila-hq.org/index.php/study-groups?study-groupsID=63, p. 5; Peters et al. (2020), p. 14.

19 Longobardo (2019), p. 50; Second Report (n. 6), p. 23; Koivurova (2010); Black-Branch (2016), p.
} 492; Bannelier-Christakis (2015), p. 26; Pisillo-Mazzeschi rather refers to 'obligations of diligent conduct'; Pisillo-Mazzeschi (1992).

${ }^{20}$ Application of the Convention on the Prevention and Punishment of the Crime of Genocide (Bosnia and Herzegovina v. Serbia and Montenegro), Judgment, ICJ Reports 2007, p. 43, para. 430; Pulp Mills on the River Uruguay (Argentina v. Uruguay), Judgment, ICJ Reports 2010, p. 14, paras. 186-187.

21 Literature also refers to this as the 'precautionary approach'; Schröder (2014), para. 3; be that as it may, its core is reflected in the UN General Assembly, Report of the United Nations Conference on Environment and Development (Rio Declaration), 12 August 1992, A/CONF.151/26 (Vol. 1), Principle 15. In the Seabed Mining Opinion, the ITLOS Seabed Disputes Chamber even considered that 'the precautionary approach has been incorporated into a growing number of international treaties and other instruments, many of which reflect the formulation of Principle 15 of the Rio Declaration. In the view of the Chamber, this has initiated a trend towards making this approach part of customary international law'; Responsibilities and Obligations of States Sponsoring Persons and Entities with Respect to Activities in the Area, Advisory Opinion, ITLOS Reports 2011, p. 10, para. 135; see also Sands et al. (2018), pp. 237 and 240 . 
This Section will briefly outline the precautionary principle as the remainder of this study will rely on and refer to this fundamental principle of international environmental law. Discussing the precautionary principle, however, cannot be done without first addressing the notion of prevention. ${ }^{22}$ In contemporary international environmental law, the aspect of prevention plays an important role as the activities on the territory of one state can have an impact on the territory of another. ${ }^{23}$ In the end, damage to the environment is commonly irreversible, restoration of the situation is frequently impossible and hazardous activities can lead to high costs. ${ }^{24}$ With that in mind, Sect. 2.1. will address the principle of prevention and Sect. 2.2 will discuss the precautionary principle.

\subsection{The Principle of Prevention}

The idea that 'prevention is rather better than the cure' has been widely admitted in international environmental law. ${ }^{25}$ This has been affirmed in arbitral awards and the case law of the International Court of Justice (ICJ), stating that the principle of prevention is now a 'principle of general international law', respectively a 'customary rule'. ${ }^{26}$ In international environmental law, the notion of prevention was famously addressed in the Trail Smelter case ${ }^{27}$ :

under the principles of international law [...] no state has the right to use or permit the use of its territory in such a manner as to cause injury by fumes in or to the territory of another or the properties or persons therein, when the case is of serious consequence and the injury is established by clear and convincing evidence. $^{28}$

\footnotetext{
${ }^{22}$ For the close relationship between prevention and precaution, see also Pulp Mills on the River Uruguay (Argentina v. Uruguay), Judgment (Separate Opinion of Judge Cançado Trindade), ICJ Reports 2010, p. 135, para. 61.

${ }^{23}$ Iron Rhine Arbitration (Belgium v. Netherlands) (PCA Award), ICGJ 2005, p. 373, para. 222.

${ }^{24}$ Gabčíkovo-Nagymaros Project (Hungary v. Slovakia), Judgment, ICJ Reports 1997, p. 7, para. 140; see also UN General Assembly, Articles on Prevention of Transboundary Harm from Hazardous Activities, 6 December 2007, A/RES/62/68; Strasser (1996), p. 7.

${ }^{25}$ Duvic-Paoli (2018), p. 1.

${ }^{26}$ See for instance Iron Rhine (n. 23), para. 59; Pulp Mills (n. 20), para. 101. For an analysis of state practice see also Sands et al. (2018), pp. 212-213.

${ }^{27}$ Trail Smelter Case (United States v. Canada), 16 April 1938 and 11 March 1941, 3 RIAA 1905; Kulesza (2016), p. 91; Bratspies and Miller (2006), pp. 2-3. Another case worth mentioning is the Alabama Claims case; Alabama Claims of the United States against Great Britain (United States v. Great Britain), 14 September 1872, 24 RIAA 125; for an analysis of the prevention principle in the Alabama Claims case and Trail Smelter case see Viñuales (2020), pp. 112-124.

${ }^{28}$ Trail Smelter (n. 27), p. 1965; Island of Palmas Case (or Mingas) (United States v. Netherlands), 4 April 1928, II RIAA 829, p. 839. Other cases worth mentioning are Corfu Channel Case (United Kingdom of Great Britain and Northern Ireland v. Albania), Merits, ICJ Reports 1949, p. 4; Lake Lanoux Arbitration (France v. Spain), 16 November 1957, 12 RIAA 281; Legality of the Threat or Use of Nuclear Weapons, Advisory Opinion, ICJ Reports 1996, p. 226, para. 29; given the limits of this study, these cases shall not be discussed.
} 
A state needs to ensure that in its jurisdiction other states' rights and interests are not violated (the 'no harm' principle). ${ }^{29}$ The breach of such obligation would occur if a state fails to take measures so as to prevent activities that have a 'serious consequence' and lead to injuries based on 'clear and convincing evidence'. According to Barnidge, the terms 'serious consequence' and 'clear and convincing evidence' show the importance of the significant nature of the injury in question. The Trail Smelter judgement, in that way, excludes de minimis injuries. ${ }^{30}$ That is to say, only materialised damage is included and not a mere risk thereof. ${ }^{31}$ As such, a state cannot be assumed to be responsible for all activities on its territory. ${ }^{32}$ What is expected from the state is that it takes reasonable measures that are available to it to prevent materialised harm. In that regard, a state is presumed to act in 'good faith' when it comes to the prevention of the harm. ${ }^{33}$

\subsection{The Precautionary Principle}

As the principle of prevention requires a state to take action to prevent environmental harm, such actions need to be taken-if possible-before damage actually has occurred. ${ }^{34}$ Following the Trail Smelter dictum, a state would only breach this duty of care if the case has a 'serious consequence' and the injury is established on 'clear and convincing evidence'. Such high thresholds suggest that action shall only be taken where there is scientific evidence that serious environmental harm will occur. ${ }^{35}$ Obtaining sufficient scientific evidence, however, is often difficult. This limitation of the principle of prevention has been widely recognised in several international legal instruments ${ }^{36}$ and in case law $^{37}$ in the form of the precautionary

\footnotetext{
${ }^{29}$ Second Report (n. 6), pp. 5-6. This is also known as 'every State's obligation not to allow knowingly its territory to be used contrary to the rights of other States'; Corfu Channel (n. 28), p. 22.

${ }^{30}$ Barnidge Jr. (2006), p. 101. Notably, Barnidge acknowledges that one might wonder what 'a case of serious consequence' would look like and what the requirements for an injury to be considered as 'established by clear and convincing evidence' are. In the context of environmental pollution, 'clear and convincing' could be associated with scientific proof that establishes a causal link between the activities in question and the environmental damage that occurs.

31 Viñuales (2020), pp. 122-123.

32 Eagleton (1928), pp. 8-9; Ellis (2006), pp. 59-60; Kulesza (2016), p. 93.

33 Even in 1941, the general rule of thumb was that the acts of non-state actors could only give rise to state responsibility if the state omitted to prevent the harm. See also Ellis (2006), p. 60; Kulesza (2016), p. 93. It needs to be mentioned that the matter of prevention forms an integral part of the obligation not to cause transboundary harm to other states (no harm principle), yet prevention is also a notion on its own in international environmental law. In that regard, the principle of prevention needs to be distinguished from the no harm principle. See also Sands et al. (2018), pp. 211-212.

34 Sands et al. (2018), p. 212; see also Gabčíkovo-Nagymaros Project (n. 24), para. 140.

35 Schröder (2014), para. 4; First Report (n. 18), p. 26.

36 See for instance Rio Declaration (n. 21), Principle 15; 1992 UNFCCC (n. 3), Art. 3(3); Vienna Convention for the Protection of the Ozone Layer, 22 September 1998, 1513 UNTS 293, Preamble; for an overall analysis of relevant legal instruments see Sands et al. (2018), pp. 230-233.

37 Examples include Southern Bluefin Tuna (New Zealand v. Japan), Provisional Measures, ITLOS Reports 1999, p. 280, paras. 77, 79 and 80; MOX Plant (Ireland v. United Kingdom), Provisional Measures, ITLOS Reports 2001, p. 95, paras. 84 and 89(1); Land Reclamation in and around the Straits of Johor (Malaysia v. Singapore), Provisional Measures, ITLOS Reports 2003, p. 10, para. 99; Activities in the Area (n. 21), paras. 121-122 and 125-127; Pulp Mills (n. 20), para. 164; Tătar v. Romania, no.
} 
principle. The rationale for this principle is that where environmental damage will be irreversible and damage cannot be repaired or only at very high expense, ${ }^{38}$ the lack of scientific proof shall not be used as a justification to postpone the taking of preventive measures. ${ }^{39}$ That is to say, even in a situation where there is only the risk of harm but it has not yet materialised, a state is required to take precautions.

Nonetheless, the legal status and exact meaning of the precautionary principle remain unclear. ${ }^{40}$ During the negotiations of the United Nations Framework Convention on Climate Change (1992 UNFCCC), reference to the precautionary principle was controversial. As a result, the eventual text adopted includes limitations on the application of the principle. Article 3(3) of the 1992 UNFCCC, for instance, requires the damage to be 'serious or irreversible'. On top of that, the provision only requires state parties to take those measures that are 'cost effective'. ${ }^{41}$ However, Article 3(3) of the 1992 UNFCCC does not contain the high threshold of 'clear and convincing evidence' as articulated in the Trail Smelter case. As such, the precautionary principle justifies a lower standard of proof. Other international legal instruments also use a lower threshold. For instance, Article 2(2)(a) of the Convention for the Protection of the Marine Environment of the North-East Atlantic (OSPAR Convention) requires its parties to take preventive action when there are reasonable grounds for concern that environmental hazards will occur, even when the harm cannot be fully scientifically proven. ${ }^{42}$

The general idea of the precautionary principle is that states need to act carefully and with foresight when it comes to activities in their jurisdiction which may have negative consequences for the environment, even when there is a lack of scientific evidence. ${ }^{43}$ However, when environmental harm can actually be proved based on 'clear and convincing evidence' the prevention principle takes over, requiring a higher degree of diligence from the state. ${ }^{44}$ This leads to the question of how due diligence is to be understood in the context of environmental pollution. To answer this question, it is useful to examine the notion of due diligence in international law.

\footnotetext{
Footnote 37 (continued)

67021/01, 27 January 2009, para. 120; for a more detailed analysis of relevant case law see Sands et al. (2018), pp. 236-239.

38 In the context of the marine environment, the 1984 Ministerial Declaration of the International Conference on the Protection of the North Sea reflected such consciousness for the first time, introducing the idea that taking precautionary measures could be based on economic grounds; Declaration of the International Conference on the Protection of the North Sea, 1 November 1984, Conclusion A.7; see also Sands et al. (2018), p. 231; Cançado Trindade (2015), pp. 404-405.

39 See also Rio Declaration (n. 21), Principle 15.

40 Although the legal status of the precautionary principle continues to evolve, there is sufficient evidence of state practice to assert that this principle is evolving into a principle of customary international law. See Activities in the Area (n. 21), para. 135; see also Sands et al. (2018), pp. 239-240.

411992 UNFCCC (n. 3), Art. 3(3); see also Rio Declaration (n. 21), Principle 15.

42 Convention for the Protection of the Marine Environment of the North-East Atlantic, 25 March 1998, 2354 UNTS 67, Art. 2(2)(a); Sands et al. (2018), p. 233.

43 Activities in the Area (n. 21), para. 131.

44 Second Report (n. 6), p. 21. Accordingly, the precautionary principle does not replace the principle of prevention. On the contrary, it gives a new dimension to it. See also Pulp Mills (Separate Opinion of Judge Cançado Trindade) (n. 22), p. 159, para. 61.
} 


\section{Due Diligence in International Law: One obligation, Two Paradigms}

As the precautionary principle is a due diligence obligation, the state needs to act diligently and with foresight when it comes to activities in their jurisdiction that may cause significant harm to the environment or the risk thereof. Risk management lies at the heart of due diligence obligations. At the same time, due diligence obligations are also used as a regulatory technique to outsource law-making and decisionmaking to the norm addressees of these obligations. This Section will address these two perspectives. To illustrate these, the precautionary principle will be used as an example for each perspective. First, Sect. 3.1 will examine due diligence obligations in the context of risk management. Fundamental to such an examination is the dichotomy of obligations of conduct and result known in civil law to hold the norm addressee accountable. Section 3.2, subsequently, will analyse due diligence obligations through a completely different lens, namely one of regulation. In this regard, a different dichotomy is used which confusingly uses the same terms as the civil law dichotomy. The terms 'obligation of conduct' and 'obligation of result' are given a totally different meaning when analysing due diligence obligations in a regulatory context. Finally, Sect. 3.3 will put together the threads and construct a working model, forming the theoretical foundation to compare due diligence obligations for the remainder of the present study.

\subsection{Obligations of Conduct and Result: An Accountability Perspective}

The distinction between obligations of conduct and of result has a long history in civil law traditions. ${ }^{45}$ Its origins can be traced back to the Roman law concept of bonus pater familias, which has systematically further developed in French law as the concept of bon père de famille. ${ }^{46}$ This entails that a person is obliged to exercise a certain degree of reasonable care when he affects other persons or their property. Such an obligation de moyens (obligation of means or conduct) needs to be distinguished from what can be called an obligation de résultat (obligation of result). ${ }^{47}$

The classic example is one of a medical doctor. If a doctor is obliged to cure his patient, he would have an obligation of result. However, a doctor would most certainly not want to commit himself to achieving such results as he cannot guarantee the patient's health at all times. On the contrary, a doctor rather assumes the obligation to do everything possible to cure his patient, which is an obligation of conduct: he needs to do everything that a 'reasonable person' and 'competent physician' placed in the same circumstances can do to look after his patient. If he fails to do so, he will be held responsible for a failure to demonstrate his 'best efforts', regardless

\footnotetext{
45 Dupuy (1999), p. 375; Mayer (2018), pp. 131-132; Crawford (2013), p. 221.

46 Parisi (1994), p. 322; Zimmerman (1996), pp. 1007-1009; Gałuskina (2017).

47 Mayer (2018), p. 131; Dupuy (1999), p. 375.
} 
of whether he would have healed his patient or not. Consequently, he is not accountable for the final outcome, but only for his conduct. ${ }^{48}$

The distinction between obligations of conduct and obligations of result is particularly meaningful for two reasons. First of all, the distinction leads to a change in the parties' burden of proof. In the case of an obligation of result, the debtor who agreed to achieve a certain result is presumed to be responsible ipso facto, unless he is able to exonerate himself by force majeure. In that way, a patient would only have to show that his doctor failed to achieve the desired result, namely healing him. The burden of proof then lies on the doctor, since he has to free himself by proving that it was impossible for him to perform his obligation. ${ }^{49}$ However, the burden of proof is different in the case of an obligation of conduct as this type of obligation does not entail responsibility ipso facto. This is favourable to the debtor since his conduct is closely related to risk management. ${ }^{50}$ If his obligation is an obligation of conduct rather than of result, he does not have to prove anything. Instead, it is the creditor that needs to prove that the debtor did not demonstrate his best efforts. In other words, the burden of proof lies not on the doctor, but on the patient. ${ }^{51}$ On top of that, the patient needs to prove the damage that was caused by the doctor's lack of care. Accordingly, proving the breach of an obligation of conduct is more difficult. ${ }^{52}$

Another practical interest for using the distinction between obligations of conduct and result is that it enables the determination of the exact moment of a violation. In the case of obligations of result, the moment of a violation occurs when the given result is not achieved. For an obligation of conduct, however, the moment of violating the norm concerns the occurrence of the situation prohibited by the norm and not the result that could have occurred because of it. ${ }^{53}$

For the above-mentioned reasons, and especially from the perspective of risk management, the civil law dichotomy has proven to be useful in the context of international environmental law and transboundary damage. ${ }^{54}$ One of the first pioneers to have introduced the civil law dichotomy in international law was Paul Reuter. ${ }^{55}$ According to him, obligations of result require a state to specifically perform a certain action, whereas an obligation of conduct requires a state to present its best efforts. ${ }^{56}$ For example, the obligation of a state to take all necessary measures to prevent environmental harm (the principle of prevention) would be an obligation of conduct and not an obligation of result. In that context, a state may be held accountable if it did not demonstrate its best efforts-even if environmental harm has not (yet) occurred. The failure of having showed sufficient care and the existence of

\footnotetext{
${ }^{48}$ Dupuy (1999), p. 375; Zimmerman (1996), p. 1009; Moons (2018), pp. 137-138; Economides (2010), p. 375 .

49 Economides (2010), p. 375; Nicolae (2014), p. 157; Moons (2018), p. 138.

50 Peters et al. (2020), p. 2.

51 Economides (2010), p. 375; Nicolae (2014), p. 158; Moons (2018), p. 138.

52 Economides (2010), p. 377.

53 Ibid., p. 377; Dupuy (1999), p. 382.

54 Dupuy (1999), p. 375.

55 Reuter (1958), pp. 56-58.

56 Longobardo (2019), p. 49.
} 
significant (risk of) environmental harm needs to be proven by the injured party. The rationale of the obligation of conduct is to release the burden of proof from the norm addressee of the obligation. In that regard, the state is presumed to act in 'good faith', thereby placing the burden of proof upon the party claiming the violation. As in civil law, it is difficult for this party to prove that the state has failed to take reasonable measures, especially when there is a lack of scientific evidence. ${ }^{57}$ In the case of a lack of scientific evidence, the precautionary principle would be applicable.

The precautionary principle can also be qualified as an obligation of conduct. As the rationale of an obligation of conduct is to place the burden of proof upon the party claiming the violation, the state is assumed to have acted in good faith. In principle, the state would not have to prove anything, yet in the case of the precautionary principle a lower 'standard of proof' is used for the party claiming the violation. The latter does not have to rely on 'clear and convincing evidence' when it comes to the existence of the risk of environmental harm. Instead, it has to prove that the state has not taken precautionary actions to become aware of the risk of environmental harm. An example is proof that the state has failed to establish a legislative or other regulatory framework which should have made it possible for it to become aware of the risk of environmental harm. ${ }^{58}$ It would then be up to the state to prove the nonexistence of the risk. ${ }^{59}$

\subsection{Obligations of Conduct and Result: A Regulatory Perspective}

As illustrated, due diligence obligations are useful in international law as regards holding a state accountable in the context of risk management. However, due diligence obligations are also used as a regulatory technique. Remarkably, the dichotomy between 'obligations of conduct' and 'obligations of result' is then used, yet the underlying idea is not the same as the civil law dichotomy. As the meaning of the terms 'result' and 'conduct' change in the context of regulation, a different dichotomy is in fact followed. This can be best explained with the work of the legal philosopher Pauline Westerman. ${ }^{60}$ According to her, in a regulatory context an 'obligation of result' merely prescribes the ends to be pursued by regulation. This

\footnotetext{
57 In the Pulp Mills case, the applicant (Argentina), for example, failed to provide sufficient evidence of the respondent having breached the relevant obligations of conduct; Pulp Mills (n. 20), paras. 189 and 265.

58 Schröder (2014), para. 4; First Report (n. 18), p. 26; this is also known as the standard of the 'balance of the evidence'. According to Foster, such a standard of proof 'would correlate with the standard of proof applied in civil cases in common law jurisdictions, that is: whether a court considers a fact to be established "on the balance of probabilities" or on the preponderance of the evidence'; Foster (2010), p. 60.

59 There is also evidence that this interpretation is supported by state practice. For this see Sands et al. (2018), p. 234; noteworthy is that Judge Greenwood criticised the ICJ for having used the wrong standard of proof in the Pulp Mills case. Basically, he argued that the high standard of proof of the prevention principle was used instead of the lower standard of proof of the precautionary principle; Pulp Mills on the River Uruguay (Argentina v. Uruguay), Judgment (Separate Opinion Judge Greenwood), ICJ Reports 2010, p. 221; see also Boyle and Harrison (2013), p. 269.

60 See Westerman (2018); for an earlier analysis in Dutch see Westerman (2008).
} 
implies that the norm addressee needs to realise certain regulatory ends, but leaves it up to the norm addressee to determine how these ends are realised. Put differently, how regulation is done is up to the norm addressee to decide, as long as the norm addressee takes measures to achieve the end result of regulation. ${ }^{61}$ The precautionary principle is a perfect example. ${ }^{62}$ This obligation requires a state to take precautionary measures and leaves a great amount of discretion as to which measures are taken to meet the regulatory end result. The required end result is that the state takes regulatory measures that it regards as necessary and appropriate to realise the required precautions to prevent environmental degradation. If, according to Westerman, the obligation concerns an 'obligation of conduct', the norm addressee is required to take specified regulatory action. The norm addressee must simply perform the specific action required by the norm to realise the end result of regulation. This leaves no regulatory discretion for the norm addressee. For example, if a treaty provision requires a state 'to create an administrative body as a precautionary measure to reach the regulatory end-goal of preventing environmental harm', the norm is very concrete and provides a clear direction: the state must establish that administrative body. This is the end result and it is not up to the state to decide whether this is the best way to implement the precautionary principle. ${ }^{63}$ Arguably, this idea of 'obligations of result' was already introduced in international law by Roberto Ago in his Sixth Report on State Responsibility in 1997. ${ }^{64}$ Although Ago's understanding of obligations of conduct and result received major criticism in the context of state responsibility, his dichotomy in fact is not useless when it comes to a regulatory perspective on due diligence obligations. ${ }^{65}$

The reason for qualifying due diligence obligations as obligations of result from a regulatory perspective is that the employment of such obligations leads to a particular mode of regulation, also known as 'outcome-based' or 'result-driven' regulation. ${ }^{66}$ This mode of regulation has the function to, what Westerman qualifies as, 'outsourced rule-making'. ${ }^{67}$ By outsourcing, Westerman neither refers to the practice of hiring external experts in order to draft rules nor to consulting online or offline practices in which the public or experts are invited to provide their input in the lawmaking. She rather refers to 'a much more radical practice' in which the outsourcer

\footnotetext{
61 Westerman (2018), pp. 31-33; Westerman also qualifies such norms as ought-to-be norms.

62 Ago and Kulesza also mention the duty of a state to 'take all necessary measure to ensure the safety of diplomatic staff' as an example; International Law Commission, Sixth Report on State Responsibility by Mr. Roberto Ago, 15 April, 7 June 5 and 15 July 1977, A/CN.4/SER.A/1977/Add.1 (Part 1), p. 9; Kulesza (2016), p. 137.

63 Westerman (2018), pp. 31-33; Westerman also qualifies such norms as 'ouht-to-do' norms. With respect to such obligations in international law, Moons provides an example in the context of the right to housing, namely 'the obligation to develop a national housing strategy'; Moons (2018), p. 141.

64 Sixth Report on State Responsibility by Mr. Roberto Ago (n. 62).

65 For criticism, see International Law Commission, State Responsibility-Comments and observations received by Governments, 25 March, 30 April, 4 May and 20 July 1998, A/CN.4/488 and Add. 1-3, pp. 123-124 and 127; Brownlie (1983), p. 241; Dupuy (1999), p. 377; Economides (2010), p. 375; Gattini (2014), pp. 35-36; Longobardo (2019), p. 49; Aust and Feihle (2020), pp. 50-51.

66 Westerman (2018), p. 4.

67 Ibid., pp. 5 and 33.
} 
formulates the desired outcomes or goals with the use of 'duties of care' ${ }^{68}$ Such norms do not indicate how the goal needs to be reached, but only require the normaddressee to demonstrate his maximum efforts. It is then within the competence of the norm addressee to decide how to attain the given goal. ${ }^{69}$

With such a mode of regulation, law-making is decentralised in many branches of international law. The reason for this is that a network of regional, national and local actors becomes more involved. In that way, expertise can be fully utilised and aspirational goals set out by the norm can effectively be reached. Regulating behaviour on the international level, after all, is a challenging task. Much depends on expertise and implementation by individual states, and the social field that is to be regulated by a branch of international law is diverse as states have their own norms, values, laws, cultures, practices and customs. In the end, specific rule-making might be in conflict with entrenched domestic rules of a state and 'cut against the grain' of state sovereignty. ${ }^{70}$ Moreover, the implementation of international norms might differ for each state. As states themselves have the best expertise to regulate further, the means to realising a regulatory end-goal are rather outsourced to the state. ${ }^{71}$ Such mode of regulation avoids the parity of obligations in favour of a flexible approach to performance. As a result, broader participation in treaty and customary regimes can be encouraged, which in the end can lead to strengthening branches of international law and the creation of customary international law in the long term. ${ }^{72}$

Clearly, there are advantages of using due diligence obligations in international law, yet the question remains what precisely happens when such obligations are used as a mode of regulation. To explain this, one can take the precautionary principle as an example: a state needs to take precautionary measures that can be reasonably expected to prevent environmental degradation. ${ }^{73}$ This obligation includes two important elements when it comes to regulation, namely an aspirational norm and an implementation norm.

The 'aspirational norm' is inherent in a due diligence obligation and describes the aim of the regulation that needs to be realised. In the case of the precautionary principle, the regulatory aim concerns the prevention of environmental degradation. The 'implementation norm' - also inherent in a due diligence obligation-refers to how this goal is to be achieved. ${ }^{74}$ In the case of due diligence obligations, precise measures are commonly not prescribed by the obligation. For example, the precautionary principle does not refer to any concrete and specific measures that need to be taken, so in that regard the state has discretion when it comes to implementation. What is clear from the due diligence obligation is that a state needs to take precautionary

\footnotetext{
68 Westerman (2008), p. 51; Westerman (2018), pp. 2-3.

69 Westerman (2018), p. 5.

70 Second Report (n. 6), p. 2.

71 Although Westerman does not analyse due diligence obligations in international law, her analysis of outsourced law-making is useful to understand the regulatory function of due diligence obligations in international law; Westerman (2008); Westerman (2013), pp. 160-166; Westerman (2018).

72 Second Report (n. 6), pp. 2-3.

73 Rio Declaration (n. 21), Principle 15.

74 Westerman (2018), p. 23.
} 
measures which can reasonably be expected from the state. In other words, the state needs to create more concrete and specific rules and policies to reach the regulatory end-goal because the precautionary principle itself does not prescribe what these rules and policies should look like.

According to Westerman, the 'aspirational norm' and 'implementation norm' usually operate with another norm to realise outsourced law, namely a 'reporting norm'. ${ }^{75}$ This norm requires the norm addressee to deliver reports on the measures that have been taken and policies that have been pursued. In that way, the reporting norm pushes the norm addressee to take measures, holding the norm addressee accountable if the reports illustrate a failure to take measures to realise the regulatory end-goal. ${ }^{76}$ However, reporting norms cannot always be found in international law-especially if the norm is not implemented in a concrete regulatory regime. In the case that no such regime is applicable, the due diligence obligation needs to be read in light of the principle of good faith. This general principle of law, after all, requires a state to perform an obligation with the genuine intention to achieve a positive result. ${ }^{77}$ In that way, the principle of good faith supplements due diligence obligations and deploys a constitutional quality in international law, persuading states to take measures and realise a regulatory aim. ${ }^{78}$

All in all, the employment of due diligence obligations leads to outsourced law. That is to say, further law-making and policy-making is outsourced to states and the latter need to concretise and specify the rather vague due diligence obligation. Therewith, aspects of due diligence obligations are outsourced as well. For example, the precautionary principle requires the state to take appropriate measures. ${ }^{79}$ The term 'appropriate' gives the state discretion as to decide how to reach the regulatory end-goal. Put differently, the state has to conduct a balancing exercise and determine which measures are reasonable to take depending on the circumstances of a given case. ${ }^{80}$ That way, the due diligence obligation requires a state to give further

\footnotetext{
75 Ibid., p. 23; Westerman, however, defines the norm as an 'accountability norm', yet such a qualification creates confusion as the term 'accountability' is used differently in this study. In earlier works, Westerman used the term 'rapportageverplichting', which translates as a 'duty to report'. In the context of the present study, such terminology is more appropriate to use. See also Westerman (2013), p. 164.

76 Westerman (2018), p. 23.

77 It needs to be mentioned that the International Court of Justice hardly refers to the term 'general principles of law' in the sense of Art. 38(1) of its Statute, but more often to general definitions, such as 'principles of international law'. Be that as it may, Wouters acknowledges that the principle of good faith is one of the most important general principles of law in the sense of Art. 38(1)(c) of the Statute of the International Court of Justice; Wouters (2007), p. 103; Statute of the International Court of Justice, 24 October 1945, 145 BSP 832, Art. 38(1)(c).

78 Nuclear Tests (Australia v. France), Jurisdiction and/or Admissibility, ICJ Reports 1974, p. 253, para. 46; Land and Maritime Boundary between Cameroon and Nigeria (Cameroon v. Nigeria: Equatorial Guinea Intervening), Preliminary Objections, ICJ Reports 1998, p. 275, para. 38; see also Kotzur (2009), para. 25.

79 For instance, in the context of transboundary watercourses, precautionary actions refer to appropriate measures. See Convention on the Protection and Use of Transboundary Watercourses and International Lakes, 6 October 1996, 1936 UNTS 269, Arts. 2(1)(2) and (5); see also Fitzmaurice (2020), p. 141.

${ }^{80}$ See also Krieger and Peters (2020), pp. 371-372.
} 
meaning to the abstract notion of reasonableness and, henceforth, an element of due diligence is outsourced to the state. ${ }^{81}$

\subsection{Accountability and Regulation: Two Different Paradigms}

Clearly, due diligence obligations can be qualified as both 'obligations of conduct' and 'obligations of result', depending on the lens through which one analyses the obligation. If due diligence obligations are analysed to hold a state accountable, the obligation would be understood as an 'obligation of conduct'. However, if the obligation is to be analysed as a mode of regulation, the term 'obligation of result' is used. Important is that this does not refer to an obligation of result as known in civil law to hold the norm addressee accountable. Instead, a completely different meaning is given to the term from a regulatory perspective. Due diligence obligations therefore operate in two paradigms at the same time. First, a due diligence obligation operates in an 'accountability paradigm'. In this paradigm, the civil law dichotomy is used as an axiom in the context of risk management. At the same time, a due diligence obligation operates in a 'regulation paradigm', where Westerman's dichotomy is used in the context of outsourced law. As the terms 'obligation of conduct' and 'obligation of result' are given an entirely different meaning in this paradigm, there is in fact no construction of due diligence obligations opposite to the civil law dichotomy. Instead, a completely different axiom is used in this paradigm. To explain this, one can compare a due diligence obligation with the phenomenon of ambiguous images.

An ambiguous image contains multiple figures, creating an ambiguity that leads to the phenomenon of multistability in perception. ${ }^{82}$ As such, a competition between interpretations of one single image arises. A classic example is the duck-rabbit illusion. ${ }^{83}$ While the image contains both a duck and a rabbit, one cannot observe both a duck and a rabbit at the same time. One perceives either a duck or a rabbit, depending on the construction made by the viewer. Exactly the same applies to the understanding of due diligence obligations. On the one hand, one can analyse a due diligence obligation in the accountability paradigm using the civil law dichotomy to determine the performance of a state's due diligence obligation. On the other hand, one can analyse a due diligence obligation in the regulation paradigm using Westerman's dichotomy with the rationale of outsourcing law-making. Having said that, one can speak of two paradigms that exist at the same time, yet one shifts from one paradigm to the other. ${ }^{84}$

Altogether, the accountability paradigm and regulation paradigm form a working model of due diligence obligations in this study. In this model, due diligence obligations operate in the two paradigms at the same time, yet the elements of due diligence function differently in each of these paradigms. ${ }^{85}$ Important is that the civil law dichotomy functions as an axiom in the accountability paradigm, while Westerman's dichotomy serves

\footnotetext{
81 See also Sect. 4, which devotes more attention to the notion of reasonableness as an important element of due diligence.

82 Schwartz et al. (2012).

83 See for instance McManus et al. (2010), p. 168.

${ }^{84}$ For the phenomenon of paradigm shifts, see Koningsveld (2006), pp. 135-136.

85 See Sect. 4. Furthermore, reference can be made to Papanicolopulu who analyses due diligence obligations related to the law of the sea in terms of 'responsibility' and 'regulation'; Papanicolopulu (2020).
} 
as an axiom in the regulation paradigm (see Table 1). Using such a working model, then, makes it possible to categorise and clarify the elements of due diligence much better, which ultimately contributes to a better understanding of due diligence in international law. As for now, this article will give no further meaning to this model nor will it expand upon this model. Instead, it will use the working model as a theoretical foundation for the comparison of due diligence obligations in international environmental law and international human rights law, in particular the Paris Agreement and the ECHR. ${ }^{86}$

\section{Due Diligence Under the Paris Agreement and the ECHR}

Contemporary climate change mitigation is primarily regulated by the UN climate change regime. Central to this regime are its three key international legal instruments: the 1992 UNFCCC ${ }^{87}$ the Kyoto Protocol to the United Nations Framework Convention on Climate Change (Kyoto Protocol) ${ }^{88}$ and the Paris Agreement. ${ }^{89}$ Collectively, these treaties form the core instruments for regulating the management of climate change. Whereas the 1992 UNFCCC forms the foundation for action and establishes an institutional framework, the Kyoto Protocol and the Paris Agreement are attempts to provide further substance to the obligations of the states parties. ${ }^{90}$

The Paris Agreement aims to enhance the implementation of the 1992 UNFCCC and to reach the underlying end-goal of the latter, namely responding to the threat of climate change. ${ }^{91}$ The Paris Agreement does this by setting out its aims and the 'long-term temperature goal' in Article 2(1). ${ }^{92}$ This provision needs to be read in conjunction with Article 4(1) Paris Agreement, which operationalises the long-term temperature goal. ${ }^{93}$ Central to achieving the objectives of the Paris Agreement are NDCs under Article 4(2) Paris Agreement. These entail efforts by each party to the Agreement to reduce national emissions and to adapt to the consequences of climate change. ${ }^{94}$ After every five years, states need to communicate an NDC, which is subsequently registered by the Secretariat. ${ }^{95}$ The underlying idea is that the parties to the Paris Agreement determine the goals related to climate change mitigation

\footnotetext{
${ }^{86}$ Further research on the expansion of this model of due diligence in international law is recommended. This could be done by studying due diligence obligations in other branches of international law. Examples are international investment law, global health law (specifically the International Health Regulations), international humanitarian law, the international law of the sea and diplomatic law.

871992 UNFCCC (n. 3).

88 Kyoto Protocol (n. 3).

89 Paris Agreement (n. 3).

90 For a comprehensive overview of these three international legal instruments, see Bodansky et al. (2017); see also Sands et al. (2018), pp. 299-331; Birnie et al. (2009), p. 356; Bodansky (1993); French (1998); Bodansky (2016).

91 Paris Agreement (n. 3), Art. 2(1); Sands et al. (2018), p. 320.

92 In this regard, the parties to the Paris Agreement commit themselves to hold the increase in global average temperature to 'well below' a $2{ }^{\circ} \mathrm{C}$ rise. At the same time, the parties pursue efforts towards a $1.5^{\circ} \mathrm{C}$ temperature limit; Bodansky et al. (2017), p. 229.

93 Mace (2016), p. 24; Sands et al. (2018), p. 321.

94 Brus (2016), p. 620.

95 Paris Agreement (n. 3), Arts. 4(9) and (12).
} 
Table 1 Accountability paradigm and regulation paradigm of due diligence obligations

Taking all precautionary measures that can reasonably be expected from a state to prevent environmental degradation (precautionary principle)

\begin{tabular}{lll}
\hline Paradigm & Accountability & Regulation \\
Axiom & Civil law dichotomy & Westerman's dichotomy \\
Type of obligation & Obligation of conduct & Obligation of result (pursuing the \\
(undertaking best efforts) & regulatory aim) \\
Rationale & Risk management & Outsourcing law \\
\hline
\end{tabular}

themselves and, at the same time, are obliged to undertake their best efforts to reach these goals. Such efforts are expected to reflect the highest ambitions to mitigate climate change and to illustrate a progression over time. ${ }^{96}$ As Bodansky, Brunnée, Rajamani and Voigt note, the duty to undertake such efforts can be best qualified as a due diligence obligation. Each party, after all, is individually required to pursue domestic measures, such as the development of domestic laws, to achieve the objective of their own mitigation NDC. ${ }^{97}$

In the context of environmental pollution, obligations of a similar type can be found under the ECHR - albeit that these are commonly known as positive obligations. ${ }^{98}$ As Stoyanova observes, the European Court of Human Rights (ECtHR) does not generally use the standard of due diligence to hold the norm addressee of a positive obligation accountable. This is especially the case when it comes to more concretised obligations, such as the obligation to criminalise and the obligation to investigate. ${ }^{99}$ With that in mind, it would not be appropriate to qualify all positive obligations under the ECHR as due diligence obligations. Strasbourg case law related to Article 8 ECHR, however, supports the idea that the general duty to protect human rights in the context of environmental pollution can be best qualified as a due diligence obligation. ${ }^{100} \mathrm{~A}$ state, for example, can be held responsible for having failed to regulate a private industry as it has an obligation to take reasonable and appropriate measures to secure the rights protected by Article 8 ECHR. ${ }^{101}$ Put differently, 'a state must take due diligence into account in its policy'. ${ }^{102}$ In the end, authorities cannot ensure that absolutely no human rights violations occur or that such human rights violations will always be prevented. At the same time, a state cannot stand by idly while a person's private life, family life and/or home is negatively affected due to environmental pollution. Accordingly, the duty to protect these rights under Article 8 ECHR puts emphasis on the measures to

\footnotetext{
96 Brus (2016), p. 620; Mace (2016), p. 35; Sands et al. (2018), p. 322.

97 Mayer (2018), p. 135; Winkler (2017), p. 147; Bodansky et al. (2017), p. 231; Bodansky (2016), p. 146; Rajamani (2016), p. 354; see also Voigt (2016).

98 For positive obligations in international human rights law and the ECHR, see Shelton and Gould (2013); Mowbray (2004); Akandji-Kombe (2007).

99 Stoyanova (2020).

100 See for instance Hatton and Others v. United Kingdom, no. 36022/97, 8 July 2003; Fadeyeva v. Russia, no. 55723/00, 9 June 2005; Jugheli and Others v. Georgia, no. 38342/05, 13 July 2017.

101 Fadeyeva v. Russia (n. 100), para. 89; Hatton and Others v. United Kingdom (n. 100), para. 98; see also Birnie et al. (2009), p. 284.

102 Urgenda (n. 1), para. 5.3.3.
} 
be taken by the state and not the achievement of the complete protection of human rights. This obligation, therefore, can be best described as a due diligence obligation as well. ${ }^{103}$ As noted by Shelton and Gould, such a classification is most appropriate as the notion of due diligence lies somewhere between the extremes of always guaranteeing absolute protection and doing nothing. ${ }^{104}$

As international environmental law and international human rights law provide rich sources for comparative experiences, this Section will compare the operation of due diligence obligations under Article 4(2) Paris Agreement with the operation of positive obligations related to the right to respect for private life, family life and the home under Article $8 \mathrm{ECHR}$. In this regard, a number of units of comparison will be discussed. At first sight, appropriate units of comparison would be the parameters that influence a state's performance of its due diligence obligations. Early judicial practice has identified numerous legal benchmarks capable of influencing the application of the notion of due diligence in international law. ${ }^{105}$ These include the foreseeability of harm or the risk thereof, ${ }^{106}$ the interest at stake, ${ }^{107}$ the capacity of the state ${ }^{108}$ and effective control by the state. ${ }^{109}$ Nevertheless, this article will not analyse these parameters as much has already been written about these elements of due diligence. ${ }^{110}$ Instead, three core elements of due diligence obligations will be

\footnotetext{
103 See also Baade (2020).

104 Shelton and Gould (2013), p. 578.

105 Important examples include Alabama Claims (n. 27); Mrs Elmer Elsworth Mead (Helen O Mead) (USA) v. United Mexican States, 29 October 1930, 4 RIAA 653; Affaire des biens britanniques au Maroc espagnol (Spain v. UK), 1 May 1925, 2 RIAA 617; Leonor Buckingham (Great Britain) v. United Mexican States, 3 August 1931, 5 RIAA 286; Bond Coleman (United States) v. United Mexican States, 3 October 1928, 4 RIAA 364; for a more in-depth analysis of these cases, see Bartolini (2020).

106 Foreseeability refers to constructive or objective knowledge, and not actual knowledge. That is to say, a state ought to have known about a risk or harm; Genocide (n. 20), para. 432; Second Report (n. 6), pp. 12-13; see also Bartolini (2020), pp. 38-39; Baade (2020), p. 98.

107 A negative outcome, regardless of its source, can have an impact on interests and rights. The general rule of thumb is the following: the more important the protected interest or right, the more necessary it becomes to take action. See also The Environment and Human Rights (State Obligations in Relation to the Environment in the Context of the Protection and Guarantee of the Rights to Life and to Personal Integrity: Interpretation and Scope of Articles 4(1) and 5(1) in Relation to Articles 1(1) and 2 of the American Convention on Human Rights), IACtHR Series A No. 23, Advisory Opinion OC-23/17, para. 142; Second Report (n. 6), p. 12; Sarkin (2018), p. 18; Bartolini (2020), pp. 38-39; Baade (2020), pp. 98-99.

108 The means at a state's disposal can counterbalance the value that needs to be given to the interest or right at stake. See for instance Genocide (n. 20), para. 430; important is that a state cannot hide behind its capacity. At the bear minimum, a state needs to build its state apparatus to provide sufficient facilitation to meet the due diligence standard. See for instance LFH Neer and Pauline Neer (USA) v. United Mexican States, 15 October 1926, 4 RIAA 60; AL Harkrader (USA) v. United Mexican States, 3 October 1928, 4 RIAA 371; Mead (n. 105), pp. 654-655; Affaire des biens britanniques au Maroc espagnol (n. 105), pp. 641-642; The Environment and Human Rights (n. 107), para. 144; Second Report (n. 6), pp. 10-11; Bartolini (2020), pp. 36-37; Baade (2020), p. 99.

109 Military and Paramilitary Activities in and against Nicaragua (Nicaragua v. United States of America), Merits, ICJ Reports 1986, p. 14, para. 115; Genocide (n. 20), paras. 399 and 406; important is that the more effective control a state has over a territory or over non-state actors, the stricter the degree of care will be. However, the mere lack of effective control rarely automatically exonerates states from their duty of care. See also Ilaşcu and Others v. Moldova and Russia, no. 48787/99, 8 July 2004, para. 331; Second Report (n. 6), pp. 11-12; Bartolini (2020), pp. 39-40; Baade (2020), p. 99.
}

110 Examples include Second Report (n. 6); Bartolini (2020); Violi (2020); Baade (2020). 
compared in this study, namely the 'character of the obligation', 'reasonableness' and 'good faith'.

Section 4.1 will first discuss the character of the obligations. This is important as the nature of human rights obligations under international human rights law is somewhat different from the nature of obligations under general international law. A comparison of the character of the obligations makes it also possible to compare due diligence obligations under the Paris Agreement with positive obligations under the ECHR through the lens of the accountability paradigm and regulation paradigm. Section 4.2 will compare the elements of reasonableness and good faith under the Paris Agreement and the ECHR in the accountability paradigm. These two elements have been selected for this study as they operate not only in the accountability paradigm, but also in the regulation paradigm. Finally, Sect. 4.3 will compare the operation of these two core elements of due diligence obligations under the Paris Agreement and the ECHR in the regulation paradigm.

\subsection{Character of the Obligation: Reciprocity and Special Character}

Due diligence obligations can be found in various branches of international law, yet their character can be qualified differently. Historically, due diligence obligations were created by consent between sovereign equals. Examples are the obligation to provide protection to foreigners and their properties, and the obligation to protect the interests and rights of other states. ${ }^{111}$ These obligations were based on reciprocity, meaning that a legal relationship between two or more states exists under international law. As a result, particular behaviour by one party is dependent upon that of another party. ${ }^{112}$ Obligations under general international law are mutual and one obligation constitutes an exchange for another. ${ }^{113}$

The reciprocal character of international obligations has a particular impact on treaties. The main idea is that treaties are freely concluded based on the sovereign equality of states and, hence, embody a mutual exchange of benefits or lay down uniformity for future behaviour. ${ }^{114}$ For example, the 1992 UNFCCC, the Kyoto Protocol and the Paris Agreement establish reciprocal rights and obligations among the state parties. In this respect, due diligence obligations related to the NDCs under the Paris Agreement operate vis-à-vis other parties to the treaty. If the obligation is breached, other states can hold the breaching state internationally responsible for violating international law. ${ }^{115}$

Positive obligations related to Article 8 ECHR, however, do not fit this model. The idea is that obligations under international human rights law deal with obligations of states towards individuals and collective groups as human rights holders,

\footnotetext{
111 Bartolini (2020), pp. 24-29.

112 Simma (2008), para. 2.

113 Sicilianos (2002), p. 1135; Mégret (2018), p. 87.

114 The profound consequences of reciprocity are especially apparent with regard to reservations to and the termination of a treaty or the suspension of its operation as a result of a breach; Simma (2008), paras. 4-5.

115 See also UN General Assembly, Articles on Responsibility of States for Internationally Wrongful Acts, 12 December 2001, A/56/83, Art. 42.
} 
rather than obligations of states towards other states. ${ }^{116}$ According to Craven, the elements of the 'form' and 'function' of a human rights obligation seem to be in conflict with each other. ${ }^{117}$ Human rights obligations are not based on the idea of reciprocity per se. States rather express their consent to be bound by these obligations, while at the same time rights for individuals within their jurisdiction are created with which these obligations operate. This has led to conceptual and practical challenges as regards the qualification of the nature of human rights obligations under international law. As noted by Mégret, the answer to this problem lies in the 'special character' of the obligations under international human rights law. ${ }^{118}$

The idea of this 'special character' of human rights obligations was accurately addressed by the Inter-American Court of Human Rights (IACtHR) in the Effect of Reservations Opinion. In this Advisory Opinion it was stated that

[m]odern human rights treaties in general, and the American Convention in particular, are not multilateral treaties of the traditional type concluded to accomplish the reciprocal exchange of rights for the mutual benefit of the contracting States. Their object and purpose is the protection of the basic rights of individual human beings irrespective of their nationality, both against the State of their nationality and all other contracting States. In concluding these human rights treaties, the States can be deemed to submit themselves to a legal order within which they, for the common good, assume various obligations, not in relation to other States, but towards all individuals within their jurisdiction. ${ }^{119}$

In other words, human rights treaties regulate inter-state behaviour while at the same time they function as a framework enabling states to unilaterally commit themselves not to violate human rights within their jurisdiction. ${ }^{120}$ As such, states commit themselves to a certain supranational standard of behaviour. ${ }^{121}$ Human rights obligations are not to be understood as being dependent on human rights obligations of other states. In contrast, states pledge themselves to a legal order within which they assume human rights obligations towards all individuals within their jurisdiction,

\footnotetext{
116 Mégret (2018), p. 88.

117 On the one hand, the form in which the rights are expressed implies that human rights treaties are agreements between states. On the other hand, the function of human rights treaty regimes is to protect third parties, namely individuals and collective groups; Craven (2000), p. 493.

118 Mégret (2018), p. 88.

119 The Effect of Reservations on the Entry into Force of the American Convention (Arts 74 and 75), IACtHR Series A No. 2, Advisory Opinion OC-2/82, para. 29.

120 Ibid., para. 33; see also The Rights to Information on Consular Assistance in the Framework of the Guarantees of the Due Process of Law, IACtHR Series A No. 16, Advisory Opinion OC-16/99, paras. 71-84.

121 Mégret (2018), p. 90; Mégret also refers to the Genocide Convention and the Reservations to the Genocide Convention Opinion by the International Court of Justice; Convention on the Prevention and Punishment of the Crime of Genocide; Reservations to the Convention on the Prevention and Punishment of the Crime of Genocide, Advisory Opinion, ICJ Reports 1951, p. 15, para. 23. However, the question remains as to whether the Genocide Convention can be qualified as a human rights treaty. Some argue that it rather belongs to international criminal law instead of international human rights law. See for instance Chinkin (2018), p. 517; Simpson (2003), p. 5.
} 
and where the obligations are exercised for the common good and not in relation to other states. ${ }^{122}$ Such 'pledges' are legally binding and limit governmental power. ${ }^{123}$

Related to this is another aspect of the special character of human rights obligations. Human rights obligations operate, as some suggest, in a similar way as legislative or even constitutional norms. The ECtHR, for instance, has referred to the ECHR as a "constitutional instrument of European public order'. ${ }^{124}$ Reference to such a constitutional character illustrates that human rights treaty regimes operate closely in relation to regional and domestic governance structures. In Mégret's view, international human rights attach all parties to a human rights system to a collective project that is both domestic and supranational in character. ${ }^{125}$ Such an understanding is relevant to note as it confirms that both the Paris Agreement and the ECHR provide an institutional framework where due diligence obligations operate. ${ }^{126}$ With that in mind, it is possible to compare the core elements of due diligence obligations through two lenses: risk management (accountability paradigm) and outsourced law (regulation paradigm).

\subsection{Accountability Paradigm}

As explained in Sect. 3, a due diligence obligation needs to be understood against the background of risk management in the accountability paradigm. The question remains how due diligence obligations operate in this paradigm. How is a state's performance of a due diligence obligation determined? Numerous arbitral awards have identified factors influencing the application of due diligence in international law. ${ }^{127}$ These parameters have to be read both individually and collectively in light of the standard of reasonableness. At the same time, the matter of good faith plays a role when it comes to the expectations of taking reasonable action. The following subsections will address these two core elements of due diligence in the accountability paradigm and compare its operation under Article 4(2) Paris Agreement with its operation under Article 8 ECHR.

\subsubsection{Reasonableness and the Degree of Care}

The concept of reasonableness derives from the principle of bonus pater familias, entailing that a person is obliged to exercise a particular degree of reasonable care when he affects other persons or their property. ${ }^{128}$ International legal practice and early legal scholars used this principle to determine the degree of care that is

\footnotetext{
122 The Effect of Reservations (n. 119), paras. 29-30.

123 Chinkin (2018), pp. 514-515; see also Brilmayer (2007).

124 Loizidou v. Turkey (Preliminary Objections), no. 15318/89, 23 March 1995, para. 75.

125 Mégret (2018), p. 91.

${ }^{126}$ For an overview of the institutional framework of the current UN climate change regime, see Bodansky et al. (2017), pp. 141-148.

127 For a clear overview of these factors that had been identified in early judicial practice, see Bartolini (2020), pp. 33-40.

128 Ibid., p. 35; see also Parisi (1994), p. 322; Zimmerman (1996), pp. 1007-1009; Gałuskina (2017).
} 
expected from a state. ${ }^{129}$ Generally speaking, the notion of reasonableness is the standard that is used to assess the relevant parameters influencing a state's performance of its due diligence obligation. ${ }^{130}$ For each individual factor, the standard of reasonableness is used to determine whether a state's behaviour is in accordance therewith. On top of that, the notion of reasonableness is used as an overarching standard to fairly balance these parameters with each other. The parameters that influence a state's performance of its due diligence obligation, consequently, interact with each other in one balancing exercise. ${ }^{131}$

Consider, for instance, a developing state that has committed itself to absolute limitation targets through its NDC under Article 4(2) Paris Agreement. If this state were to undergo an unexpected decade of economic crisis and, as a result, would not able to take those measures that it initially planned, the state is likely to have less means at its disposal to reach its targets. In such a context, it would be unreasonable to expect from the state that it still has to pursue the original efforts that it originally planned; the parameter of the 'capacity of the state' limits the level of efforts it can pursue. Consequently, a state would likely not breach its due diligence obligation as long as it has still taken those reasonable measures at its disposal. ${ }^{132}$ Otherwise an impossible or disproportionate burden would be imposed on the state. ${ }^{133}$

In the context of human rights protection, the ECtHR takes a similar approach by referring to a fair balance test. ${ }^{134}$ ECtHR case law on environmental pollution related to Article $8 \mathrm{ECHR}$, furthermore, shows that the element of reasonableness is used to fairly balance all relevant interests. An example is one of the earliest environmental cases related to Article 8 ECHR: Powell and Rayner. ${ }^{135}$ In this case, the applicants lived under the flight path of aircraft departing from and arriving at Heathrow Airport, and claimed that the excessive levels of aircraft noise affected their lives. As such, they argued that the United Kingdom (UK) had violated Article 8 ECHR. The ECtHR agreed with the applicants as their quality of private life was affected by the noise caused by the aircraft. ${ }^{136}$ However, the ECtHR explained that a fair balance had to be struck between the competing interests of the individual (a violation of Article $8 \mathrm{ECHR}$ ) and the community as a whole (economic well-being)

\footnotetext{
129 Bartolini (2020), p. 35.

130 Sarkin (2018), p. 18; Hakimi (2010), p. 372.

131 The ILA Study Group on Due Diligence in International Law also refers to 'reasonableness' as an overarching standard; Second Report (n. 6), p. 7; in the context of human rights protection, Baade has identified such a balancing exercise. Although he does not expressly refer to reasonableness, the language of reasonableness can be read in his discussion of the several parameters influencing a due diligence obligation; Baade (2020), pp. 97-101.

132 See also Mayer (2018), pp. 136-137; Rajamani (2020), pp. 173-177.

133 Ilaşcu (n. 109), para. 332.

134 When it comes to determining the scope of a positive obligation, the Court states that 'regard must be had to the fair balance that has to be struck between the general interest and the interests of the individual, the diversity of situations obtaining in Contracting states and the choices which must be made in terms of priorities and resources. Nor must these obligations be interpreted in such a way as to impose an impossible or disproportionate burden'; ibid.
}

135 Powell and Rayner v. United Kingdom, no. 9310/81, 21 February 1990.

136 Ibid., para. 40. 
and, with that in mind, the Court rejected the applicants' argument. According to the Court, the balance had not been upset due to the airport being necessary for the economic well-being of the UK. The government, moreover, had taken significant regulatory measures to reduce, control and compensate for aircraft noise. ${ }^{137}$

Another example can be found in Hatton and Others, in which the matters of Powell and Rayner were revisited. ${ }^{138}$ For the fair balance test, the Grand Chamber eventually took several factors into consideration. These were the difficulties in establishing a policy to decline noise disturbance throughout the night, ${ }^{139}$ the contribution of the night flights to the general economy, ${ }^{140}$ the measures that were in place at Heathrow Airport to mitigate the effects of the noise disturbance, ${ }^{141}$ the fact that the few people affected could move from the area without financial loss ${ }^{142}$ and the fact that the authorities consistently monitored the situation. ${ }^{143}$ In that regard, the Grand Chamber found that a fair balance was struck by the UK and, thus, no violation of Article 8 ECHR had taken place. ${ }^{144}$

\subsubsection{Good Faith, Precaution and the Burden of Proof}

Equally important to a due diligence obligation is the notion of 'good faith'. In the accountability paradigm, the element of good faith is inherent in the nature of a due diligence obligation. Since due diligence obligations are qualified as obligations of conduct in this paradigm, the norm addressee is expected to undertake his efforts in good faith: a state cannot act diligently when it has acted in bad faith or has knowingly refused to take any action. ${ }^{145}$ For instance, parties to the Paris Agreement are expected to take action in good faith to the extent that their resources and capacities permit in achieving their NDCs. ${ }^{146}$ As explained in Sect. 3, this has consequences for the burden of proof. In the case of a breach of a due diligence obligation, the burden of proof lies upon the party claiming a violation. ${ }^{147}$ It is expected that the state undertakes efforts in good faith and, with that in mind, the party claiming a violation of the due diligence obligation must prove that the state has acted in bad faith and demonstrated negligence. However, in cases of severe environmental damage that can occur without taking measures, a state can be required to take precautionary actions even if harm has not yet materialised. ${ }^{148}$ In that case, a state cannot hide behind the high threshold of the principle of prevention (significant and clear

\footnotetext{
137 Ibid., para. 43.

138 Hatton and Others v. United Kingdom (n. 100).

139 Ibid., paras. 124-125.

140 Ibid., para. 126.

141 Ibid., paras. 74 and 127.

142 Ibid., para. 127.

143 Ibid., para. 128.

144 Ibid., paras. 129-130.

145 Second Report (n. 6), p. 13.

146 Rajamani (2020), p. 179.

147 See Sect. 3.1.

148 See Sect. 2.2.
} 
evidence that has to be proved by the potential injured party). ${ }^{149}$ Instead, the precautionary principle makes it possible to lower the standard of proof for the injured party when there is a risk of severe environmental harm. As a result, the burden of proof practically shifts to the state as justified by the precautionary principle. ${ }^{150}$

In the case of Article 4(2) Paris Agreement, such understanding is not explicitly referred to in the text of the treaty. The text itself only refers to the obligation to "pursue domestic mitigation measures, with the aim of achieving the objectives of such contributions'. ${ }^{151}$ Although the Paris Agreement does not expressly refer to the precautionary principle, the provision needs to be read in the context of the UNFCCC regime as a whole. ${ }^{152}$ With that in mind, the Paris Agreement is to be understood against the backdrop of the principles laid out in the 1992 UNFCCC, one of which is the precautionary principle. ${ }^{153}$ The efforts that have to be taken to mitigate climate change under Article 4(2) Paris Agreement can thus be viewed as precautionary measures due to the application of Article 3(3) 1992 UNFCCC. As such, states are required to take precautionary measures at the bear minimum. The precautionary principle then lowers the standard of proof for an injured party if it holds a state party internationally responsible for breaching Article 4(2) Paris Agreement. In that way, the burden of proof practically shifts to the state, which then has to show that the risk of environmental damage will not be severe in nature.

In the context of positive obligations under Article 8 ECHR, the ECtHR has made explicit reference to the precautionary principle. ${ }^{154}$ Accordingly, it becomes possible to consider the precautionary principle as a legal basis for lowering the standard of proof for the injured party. The Court, however, has never explicitly referred to the principle as a justification for lowering the standard of proof for the injured party in relation to positive obligations under Article 8 ECHR. What it could have done in its case law on environmental pollution was to refer to Article 31(3)(c) of the Vienna Convention on the Law of Treaties (VCLT). ${ }^{155}$ The precautionary principle as expressed in Article 3(3) 1992 UNFCCC, after all, is a relevant norm of international law that is to be interpreted 'together with' the context. The context is clearly that of significant environmental harm. ${ }^{156}$

As the precautionary principle makes it possible for the ECtHR to lower the standard of proof for an injured party, the ECtHR remarkably lowers the standard of proof for the party claiming a violation to the point that the latter does not have

\footnotetext{
149 Trail Smelter (n. 27), p. 1965.

150 See Sect. 3.1.

151 Paris Agreement (n. 3), Art. 4.

152 According to Art. 31(2)(a) of the Vienna Convention on the Law of Treaties, a contextual interpretation includes 'any agreement relating to the treaty which was made between all the parties in connection with the conclusion of the treaty'; Vienna Convention on the Law of Treaties (VCLT), 27 January 1980, 1155 UNTS 331, Art. 31(2)(a).

1531992 UNFCCC (n. 3), Art. 3(3).

154 Tătar v. Romania (n. 37), para. 120.

155 Art. 31(3)(c) reads: 'There shall be taken into account, together with the context: any relevant rules of international law applicable in the relations between the parties'; VCLT (n. 152), Art. 31(3)(c).

156 See also Oil Platforms (Islamic Republic of Iran v. United States of America), Judgment, Separate Opinion of Judge Higgins, ICJ Reports 2003, p. 225, para. 46.
} 
to prove anything. The Court then acts proprio motu and directly assesses positive obligations - even if the party claiming a violation has not even referred to it. For this, an effet utile interpretation is used as the basis for the Court acting proprio motu and lowering the standard of proof for the claiming party to such an extent. ${ }^{157}$ The state will thus have the burden to show that it had acted in good faith, implying that it is assumed that the state has acted in bad faith. Noticeably, this is rather a characteristic of an obligation of result in the accountability paradigm. ${ }^{158}$ A due diligence obligation, in contrast, is based on the expectation that the state acts in good faith, but since the Court lowers the standard of proof for the injured party to such an extent, it is rather expected that the state has acted in bad faith. This is completely the opposite of the rationale of due diligence obligations under which it is expected that the state performs its obligations in good faith when it comes to risk management.

\subsection{Regulation Paradigm}

In the regulation paradigm, the notions of 'reasonableness' and 'good faith' operate in a rather different way than in the accountability paradigm. The reason for this is that these elements of due diligence have to be read in light of the level of discretion given to the state, leading to outsourced law as a mode of regulation. ${ }^{159}$ The following subsections will explore these matters in relation to the NDCs under the Paris Agreement and the positive obligations under Article 8 ECHR.

\subsubsection{Reasonableness, Discretion and Margin of Appreciation}

As the Seabed Mining Advisory Opinion noted, a due diligence obligation requires its norm addressee to take measures which are 'reasonably appropriate'. ${ }^{160}$ Nonetheless, such an open-ended and vague formulation requires an evaluation of what can be expected from a state. Such an assessment is affected by the flexibility of due diligence obligations. States have choices of means that they can employ when they are expected to take reasonable measures. Due diligence obligations, accordingly, provide a certain amount of discretion to a state in deciding which precise measure can be taken in order to fulfil its obligation. ${ }^{161}$ In the end, the obligation does not provide a predefined list of measures that need to be taken. This would cut against the grain of state sovereignty and the decentralised nature of international law. ${ }^{162}$ Instead, due

\footnotetext{
157 The question remains as to whether this is a convincing justification for a shift of the burden of proof to the state in the case of positive obligations entailing that a state has to exercise due diligence. An arguably better justification would be a precautionary principle to protect human rights in general. In fact, Baade refers to the duty of states to take precautions in the context of human rights protection; Baade (2020), p. 98; Longobardo also takes note of the 'principle of precaution' in the context of international humanitarian law; Longobardo (2020), p. 188.

158 See Sect. 3.1.

159 See Sect. 3.2.

160 Activities in the Area (n. 21), para. 120.

161 Second Report (n. 6), pp. 7-8; Papanicolopulu (2020), p. 152.

162 Second Report (n. 6), p. 2.
} 
diligence obligations are flexible, and their content may change over time in light of new developments and changes to the risk involved. ${ }^{163}$ This being said, the assessment of what entails a reasonable measure, in fact, is outsourced to the states, leaving to them to decide what is reasonable. ${ }^{164}$

A perfect example illustrating this is the matter of the NDCs under the Paris Agreement. According to Article 4(2) Paris Agreement, states have a duty to pursue domestic mitigation measures with the aim of achieving the objectives of such contributions. Accordingly, it is expected that the efforts by a state will represent a progression over time. The state, however, has discretion as regards the nature of these efforts and how these will represent progression over time. ${ }^{165}$ In that way, states have to determine the most appropriate measures to be taken in conformity with their due diligence obligation. In other words, the element of reasonableness is outsourced to the states. The Paris Agreement takes it even one step further. States do not only have significant discretion in light of the measures they can take. They also have discretion when it comes to setting the targets that need to be reached with the measures taken. In that way, the NDCs are self-selected. ${ }^{166}$ Although states are clearly left with a great amount of discretion, this is not ultimately what determines which measures are reasonable. The Paris Agreement includes normative expectations ('progression', 'highest possible ambition' and 'leadership') which provide a minimum direction to states performing their due diligence obligations related to their NDCs. As such, an assessment of the degree of care required by states is guided by an 'elaborate tapestry of normative expectations placed on states' ${ }^{167}$

Under the ECHR, the discretion that states have in choosing the necessary means has also been acknowledged. In an attempt to balance national views of human rights with a uniform application of the ECHR, the ECtHR has developed what is known as the margin of appreciation. ${ }^{168}$ The margin of appreciation lays down a minimum standard that is to be achieved, whilst particular specificities of a particular state need to be taken into account. ${ }^{169}$ The implementation of human rights obligations, after all, requires an adaptation to several aspects, such as the history, political, social and cultural specificities of a state. ${ }^{170}$ Accordingly, the margin of appreciation

\footnotetext{
$\overline{163}$ Activities in the Area (n. 21), para. 117.

164 Westerman also explains that the norm addressee has the freedom of choice as to how such norms would be complied with; Westerman (2018), pp. 32-33; note, however, that national discretion in the choice of means can be limited in two ways. Firstly, the primary norm explicitly prescribes certain means, such as specific duties to legislate in order to prevent and repress certain conduct. Secondly, a specific type of measure is indispensable to avoid a negative outcome; Second Report (n. 6) pp. 7-8.

165 Brus (2016), p. 620; Mace (2016), p. 35; Sands et al. (2018), p. 322; Rajamani (2020), p. 169.

166 Rajamani also concludes that the current climate change regime builds on self-determined goals, discretion, differentiation and flexibility; Rajamani (2020), p. 180.

167 Ibid., p. 173; see also Voigt (2016).

168 Arai-Takahashi (2002), p. 3.

169 Mégret (2018), p. 102.

170 With that in mind the ECtHR has declared that "the main purpose of the Convention is "to lay down certain international standards to be observed by the Contracting states in their relations with persons under their jurisdiction". This does not mean that absolute uniformity is required and, indeed, since the Contracting states remain free to choose the measures which they consider appropriate, the Court cannot be oblivious of the substantive or procedural features of their respective domestic laws'; The Sunday Times v. United Kingdom (No. 1), no. 6538/74, 26 April 1979, para. 61.
} 
is to be understood against the backdrop of the lack of an absolute uniform implementation in the European context. As the parties to the ECHR are the ones closest to the social field that needs to be regulated, the rationale for the margin of appreciation is that states are better suited to make assessments of which measures need to be taken. ${ }^{171}$ In that way, it has been argued that the margin of appreciation is rooted in the principle of subsidiarity. ${ }^{172}$

In the context of environmental pollution and positive obligations under Article $8 \mathrm{ECHR}$, the margin of appreciation operates closely with the fair balance test. In that regard, it is possible to consider the notion of reasonableness as the other side of the margin of appreciation: the more intense the fair balance test is exercised by the Court, the narrower the margin of appreciation of the state becomes. ${ }^{173}$ For instance, in Guerra and Others the ECtHR examined whether necessary steps had been taken by Italy to ensure the effective protection of the applicants' right to respect for their private and family life due to environmental pollution from a nearby waste treatment plant. ${ }^{174}$ In this respect, the essential information that would have been necessary was not given to the applicants. ${ }^{175}$ The Court clearly applied the standard of reasonableness to these procedural matters and gradually narrowed down the abstract positive obligation so that in the end only one measure would have been sufficiently effective. ${ }^{176}$ As there would be no room for any 'middle-ground', no reference to the margin of appreciation was even made by the Court. ${ }^{177}$ In the end, the state had failed to take this measure and thus the ECtHR concluded that there had been a violation of Article 8 ECHR. ${ }^{178}$

Nevertheless, a state might have a wide margin of appreciation depending on the process of balancing the individual rights involved as protected by Article $8 \mathrm{ECHR}$ and countervailing interests, like economic well-being. ${ }^{179}$ For example, Powell and Rayner and Hatton and Others demonstrate that the Court acknowledges a wide margin of appreciation. ${ }^{180}$ However, where nuisance exceeds reasonable levels, the Strasbourg Court instead intensifies the standard of reasonableness to override a state's margin of appreciation. ${ }^{181}$ In view of this, the Court still engages in its own

\footnotetext{
171 See for instance Ireland v. United Kingdom, no. 5310/71, 18 January 1978, para. 207; in this case, the Court stated that ' $[\mathrm{b}] \mathrm{y}$ reason of their direct and continuous contact with the pressing needs of the moment, the national authorities are in principle in a better position than the international judge to decide both on the presence of such an emergency and on the nature and scope of derogations necessary to avert it'; Mégret (2018), p. 102; Kratochvil (2011), p. 326.

172 Arai-Takahashi (2002), p. 3; for an extensive analysis of the similarities between the margin of appreciation and the principle of subsidiarity see Carozza (2003).

173 Arai-Takahashi (2002), pp. 14-15.

174 Guerra and Others v. Italy, no. 14967/89, 19 February 1998, para. 58. The Court also referred to Airey v. Ireland, no. 6289/73, 19 October 1979, para. 32.

175 Guerra and Others v. Italy (n. 174), para. 60.

176 For an overall analysis of the way in which the ECtHR gradually lowers the level of abstraction of due diligence obligations, see Baade (2020), pp. 101-104.

177 Arai-Takahashi (2002), p. 81.

178 Guerra and Others v. Italy (n. 174), para. 60.

179 Arai-Takahashi (2002), p. 80.

180 Powell and Rayner v. United Kingdom (n. 135), paras. 43-44; Hatton and Others v. United Kingdom (n. 100), para. 123; see also Arai-Takahashi (2002), p. 80.

181 See for instance López Ostra v. Spain, no. 16798/90, 9 December 1994, para. 58; Arai-Takahashi (2002), p. 80 .
} 
review of the merits and occasionally determines what would be reasonable without restraining itself from rigorous judicial scrutiny. If the matter of discretion were to be given sincere meaning, the fair balance test would actually be outsourced to the state as is done under the Paris Agreement. Since this does not seem to be the case in some situations for the ECHR, the margin of appreciation might be considered as a gesture to balance deference to state sovereignty with the Court's supervision of effective human rights protection. ${ }^{182}$

\subsubsection{Good Faith and Reporting}

As the ILA Study Group on Due Diligence in International Law has noted, '[a] state cannot be considered to have acted diligently when the state has acted in bad faith or has knowingly refused to take any measures whatsoever'. ${ }^{183}$ From a regulatory perspective this is relevant, especially with respect to pushing and realising states to take action. As explained in Sect. 3, a due diligence obligation contains two regulatory elements, namely an aspirational norm and an implementation norm. ${ }^{184}$ However, without a third aspect that pushes the norm addressee to take actual action, the due diligence obligation would only refer to an aspiration and nothing more than a minimum of 'try and do something' would be expressed in that way. ${ }^{185}$ The actual realisation of the aspiration of the obligation cannot be guaranteed due to the great amount of discretion given to states. In this respect, the notion of good faith fills this gap and pushes states to realise the regulatory aim of a due diligence obligation. ${ }^{186}$ That way, good faith 'deploys a certain kind of constitutional quality within the international law scheme and beyond that is conceived to be the very foundation of all law'. ${ }^{187}$

\footnotetext{
182 According to Arai-Takahashi, one of the views on the margin of appreciation is that it could be viewed as "a rhetorical device used to "soften" the impact of adverse findings, or to give the Strasbourg judges some sense of protection against possible criticism for "judicial activism" or for "usurpation" of their mandate when deciding against a national measure'; Arai-Takahashi (2002), p. 232.

${ }^{183}$ Second Report (n. 6), p. 13.

184 See Sect. 3.2.

185 See also Papanicolopulu (2020), p. 157; Papanicolopulu distinguishes 'due diligence obligations' from obligations that only require a state to 'try and do something'. Such a distinction, however, fails to take into consideration the fact that 'try and do something' is in fact part of a due diligence obligation. This refers to the aspirational norm in the regulation paradigm and the international minimum standard in the accountability paradigm. The obligation, in fact, would be meaningless if it was not to be interpreted as an obligation that requires the norm addressee to take appropriate measures. Measures have to be taken with reason, otherwise the state's conduct concerns negligence in the accountability paradigm. This clearly shows that due diligence obligations operate in both paradigms at the same time.

${ }^{186}$ In this regard, the ICJ has also acknowledged that 'one of the basic principles governing the creation and performance of legal obligations, whatever their source, is the principle of good faith'; Nuclear Tests (n. 78), para. 46.

187 Kotzur (2009), para. 25.
} 
According to Rajamani, the notion of good faith influences the nature and extent of due diligence obligations under the Paris Agreement. ${ }^{188}$ The good faith expectation related to the NDCs, however, is further supplemented by more concrete procedural obligations that can be qualified as reporting norms. As explained in Sect. 3, these norms require the state to deliver reports on the measures that have been taken and policies that have been pursued, but can even require the states to account for future plans that they have developed. ${ }^{189}$ For instance, the ambition cycle of the NDCs requires states to communicate their NDC in which they are expected to show progression every five years. ${ }^{190}$ Such a concrete procedural obligation supplements the open-ended due diligence obligation under Article 4(2) Paris Agreement and ensures that the Conference of Parties (COP) can supervise whether states have made serious efforts to reach their self-determined goals. As a result, a compliance relationship between the COP and the Parties to the Paris Agreement is created, meaning that the state is propelled to reach its self-determined regulatory goal within five years. If it fails to do so, it can be held accountable. With that in mind, compliance and further progression is to be realised.

While the due diligence obligation under Article 4(2) Paris Agreement is supplemented by concrete procedural obligations, such is not the case for positive obligations related to Article $8 \mathrm{ECHR}$. In the human rights context, the idea of state sovereignty and diverse cultural, social and legal traditions of each state party lead to difficulties related to supervision by the ECtHR and the identification of a unified standard of human rights. Arai-Takahashi accordingly considers that the enforcement of the Strasbourg organs' undertaking ultimately depends on the good faith and continuing cooperation of the contracting states' since ' $[\mathrm{t}]$ he Convention's enforcement system depends on the mandate and consent of member states'. ${ }^{191}$ Considering this, the ECtHR has arguably developed the margin of appreciation out of necessity to balance the devotion to both state sovereignty and the supervision of human rights. ${ }^{192}$ This implies that the ECHR provides a minimum standard of human rights protection. ${ }^{193}$ Insofar as national authorities comply with this standard of protection, they have discretion when choosing the necessary means and assessing the impact that a measure can have on their citizens. ${ }^{194}$ This discretion, however, is not supplemented by more procedural obligations which push the state towards realising the aspiration set out by positive obligations under the ECHR. To that extent, the

\footnotetext{
188 Rajamani (2020), p. 179.

189 Westerman (2018), pp. 23-24.

190 Paris Agreement (n. 3), Arts. 4(3), 4(9) and (12); Rajamani also identifies other relevant provisions that underline the good faith expectation. See Rajamani (2016), p. 354.

191 Arai-Takahashi (2002), pp. 3 and 17.

192 Ibid., p. 17.

193 See also Evrigenis (1982), pp. 137-138.

194 Arai-Takahashi (2002), p. 17; Baade (2020), p. 101.
} 
Table 2 Comparing the NDCs under the Paris Agreement with positive obligations under the ECHR

\begin{tabular}{|c|c|c|}
\hline & NDCs (Art. 4(2) Paris Agreement) & $\begin{array}{l}\text { Positive obligations (Art. } 8 \\
\text { ECHR) }\end{array}$ \\
\hline Character & Reciprocal character & Special character \\
\hline $\begin{array}{l}\text { Reasonableness (accountabil- } \\
\text { ity paradigm) }\end{array}$ & $\begin{array}{l}\text { Overarching standard determining } \\
\text { the degree of care }\end{array}$ & $\begin{array}{l}\text { Overarching standard determin- } \\
\text { ing the degree of care }\end{array}$ \\
\hline $\begin{array}{l}\text { Good faith (accountability } \\
\text { paradigm) }\end{array}$ & $\begin{array}{l}\text { Standard of proof lowered for injured } \\
\text { party due to the precautionary } \\
\text { principle }\end{array}$ & $\begin{array}{l}\text { Standard of proof significantly } \\
\text { lowered to nil level due to } \\
\text { effet utile interpretation }\end{array}$ \\
\hline $\begin{array}{l}\text { Reasonableness (regulation } \\
\text { paradigm) }\end{array}$ & Completely outsourced & Less outsourced \\
\hline $\begin{array}{l}\text { Good faith (regulation para- } \\
\text { digm) }\end{array}$ & Supplemented by reporting norms & $\begin{array}{l}\text { Not supplemented by reporting } \\
\text { norms }\end{array}$ \\
\hline
\end{tabular}

due diligence obligations under the Paris Agreement operate in a stronger regulatory framework than the positive obligations under the ECHR (Table 2).

\section{Conclusions, Reflection and Further Research}

From the present study, it can be concluded that the core elements of due diligence obligations concern 'reasonableness' and 'good faith'. These notions operate in both the accountability paradigm and regulation paradigm (see Fig. 1). Moreover, a reflection on the present comparative study illustrates that due diligence in the context of climate change mitigation is a qualifier of behaviour attached to obligations that can be found in two separate legal frameworks: the Paris Agreement and the ECHR. With that in mind, the due diligence that has to be exercised by a state needs to be understood in a systemic way. Attaching due diligence to only one obligation under one legal framework would result in due diligence not being truly effective. The operation of the obligations under both the Paris Agreement and the ECHR, after all, has its strengths and weaknesses. However, when reading due diligence in a holistic manner the weaknesses of an obligation in one regime are rectified by the strengths of an obligation in the other.

For instance, under the ECHR the margin of appreciation of a state can be overridden by the employment of a strict standard of reasonableness by the Court, while at the same time the aspiration element of a positive obligation under the ECHR significantly depends on good faith instead of concrete reporting norms. In that way, states are less pushed towards the realisation of the regulatory end-goal and the implementation thereof. At the same time, states are given a great amount of discretion under the Paris Agreement, contributing to more treaty participation and universal action against climate change. This does not mean that states have unlimited discretion as regards taking 'any action' or acting in the name of 'just doing 


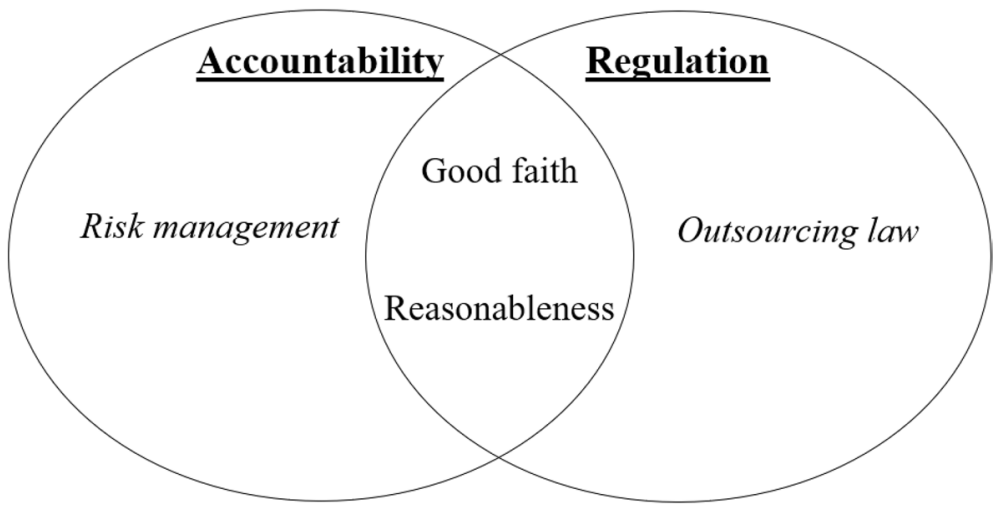

Fig. 1 A working model for due diligence and its 'core elements'

something'. A strong institutional framework of the UNFCCC regime and several procedural obligations, after all, push towards the implementation of the due diligence obligations under the Paris Agreement. ${ }^{195}$ As such, the lack of procedural obligations under the ECHR to realise the degree of care that needs to be exercised by a state is covered by the regulatory operation of due diligence obligations under the Paris Agreement, which includes more concrete procedural obligations. To that extent, the Paris Agreement provides significant meaning to the regulatory component of due diligence in climate change mitigation. ${ }^{196}$

In contrast, the component of risk management is much more developed under the ECHR, especially when it comes to the assessment of reasonableness. Case law by the ECtHR points out that the Strasbourg Court employs the standard of reasonableness. As such, more guidance for the determination of what an 'appropriate measure' means has been provided by the Court. However, under the Paris Agreement the balancing exercise determining an appropriate measure is completely outsourced to the states. With that in mind, further concretisation and specification of an 'appropriate' measure depends on state practice that must be developed. Currently, it is difficult to assert whether a uniform standard for assessing 'reasonableness' has developed in relation to the NDCs under the Paris Agreement. However, against the backdrop of the ECHR a clearer picture of what an 'appropriate measure' entails is provided. Therefore, it can be said that the accountability paradigm of due diligence is further operationalised by the ECtHR. ${ }^{197}$

\footnotetext{
195 The clear and strong institutional framework of the UNFCCC regime makes it a rich source for further research on the regulation paradigm of due diligence obligations in international law.

${ }^{196}$ It should be noted that the many reporting norms and procedural obligations under the Paris Agreement make this international legal instrument a rich source for further studies on the regulation paradigm of due diligence obligations in international law.

${ }^{197}$ However, further research is suggested on the matter of lowering the standard of proof by the ECHR. Especially the applicability of the precautionary principle in international human rights law deserves further critical assessment. See also Sect. 4.2.2.
} 
In conclusion, the operation of due diligence obligations in international environmental law and international human rights law have implications for systemic issues in international law. ${ }^{198}$ In the end, a state is required to exercise due diligence and take appropriate measure to mitigate climate change. The obligations to which this qualifier of behaviour is attached can be found in multiple branches of international law, interacting with each other. Furthermore, the working model of due diligence obligations as constructed in this study illustrates that these types of obligations have two functions: one related to risk management and the other related to a mode of regulation. ${ }^{199}$ There are good prospects for using such a working model in international law as it makes it possible to shed light on new perspectives regarding the legal entitlements of subjects of international law. ${ }^{200}$ Moreover, this working model can further clarify the operation and impact of due diligence in numerous branches of international law. ${ }^{201}$ For instance, elements of a due diligence obligation other than 'reasonableness' and 'good faith' might operate in both the accountability paradigm and the regulation paradigm or only in one. ${ }^{202}$ All in all, the rise of due diligence cannot be denied and, on that note, it is crucial to conduct further studies on this familiar stranger in international law.

Acknowledgements The author wishes to thank Prof. Dr. M.M.T.A. Brus and Prof. Dr. P. Merkouris for their supervision of this study and their valuable comments and suggestions, as well as the Editorial Board of the Netherlands International Law Review for their suggestions on earlier versions of this article. All errors are the author's own.

Open Access This article is licensed under a Creative Commons Attribution 4.0 International License, which permits use, sharing, adaptation, distribution and reproduction in any medium or format, as long as you give appropriate credit to the original author(s) and the source, provide a link to the Creative Commons licence, and indicate if changes were made. The images or other third party material in this article are included in the article's Creative Commons licence, unless indicated otherwise in a credit line to the material. If material is not included in the article's Creative Commons licence and your intended use is not permitted by statutory regulation or exceeds the permitted use, you will need to obtain permission directly from the copyright holder. To view a copy of this licence, visit http://creativecommons.org/licen ses/by/4.0/.

\footnotetext{
198 Krieger, Peters and Kreuzer also note that due diligence is an indicator for a structural change in the international legal order. See Peters et al. (2020), pp. 17-19; Krieger and Peters (2020), pp. 376-386.

${ }^{199}$ Krieger and Peters also identify these two functions by referring to them as a 'regulatory technique' and 'creating accountability'; Krieger and Peters (2020), pp. 351-352.

200 An example is the right to self-determination of indigenous peoples. Contemporary legal literature has not yet analysed this fundamental norm through the lens of the due diligence obligations of states.

201 An example would be International Health Regulations by the World Health Organisation. Recent studies have mostly focussed on matters related to the accountability paradigm of due diligence obligations or only touched the surface of its operation in the regulation paradigm. See Coco and de Souza Dias (2020a, b, c); Luca Burci (2020); Toebes et al. (2020); Further research on due diligence obligations as a regulatory technique under the International Health Regulations is suggested.

${ }^{202}$ The international minimum standard that needs to be taken into consideration when assessing the means at a state's disposal could be an example. This element can also be qualified as the aspirational norm of a due diligence obligation. In that way, this element of a due diligence obligation might operate as the international minimum standard in the accountability paradigm and the aspirational norm in the regulation paradigm.
} 


\section{References}

Akandji-Kombe J-F (2007) Positive obligations under the European Convention on Human Rights: a guide to the implementation of the European Convention on Human Rights. Council of Europe, Strasbourg

Arai-Takahashi Y (2002) The margin of appreciation doctrine and the principle of proportionality in the jurisprudence of the ECHR. Intersentia, New York

Aust HP, Feihle P (2020) Due diligence in the history of the codification of the law on state responsibility. In: Krieger H, Peters A, Kreuzer L (eds) Due diligence in the international legal order. Oxford University Press, Oxford, pp 42-58

Baade B (2020) Due diligence and the duty to protect human rights. In: Krieger H, Peters A, Kreuzer L (eds) Due diligence in the international legal order. Oxford University Press, Oxford, pp 92-108

Bannelier-Christakis K (2015) Cyber diligence: a low-intensity due diligence principle for low-intensity cyber operations? Baltic Yearb Int Law 14:23-39

Barnidge RP Jr (2006) The due diligence principle under international law. Int Community Law Rev 8:81-121

Barnidge RP Jr (2008) Non-state actors and terrorism: applying the law of state responsibility and the due diligence principle. TMC Asser Press, The Hague

Bartolini G (2020) The historical roots of the due diligence standard. In: Krieger H, Peters A, Kreuzer L (eds) Due diligence in the international legal order. Oxford University Press, Oxford, pp 23-41

Birnie PW, Boyle AE, Redgwell C (2009) International law and the environment. Oxford University Press, Oxford

Black-Branch J (2016) Due diligence as a legal concept to ensure security and safety of peaceful uses of nuclear energy as well as non-proliferation and disarmament obligations. In: Nuclear non-proliferation in international law, vol III: Legal aspects of the use of nuclear energy for peaceful purposes. TMC Asser Press, The Hague

Bodansky D (1993) The United Nations Framework Convention on Climate Change: a commentary. Yale J Int Law Online 18:451

Bodansky D (2016) The legal character of the Paris Agreement. Rev Eur Community Int Environ Law 25:142-150

Bodansky D, Brunnée J, Rajamani L (2017) International climate change law. Oxford University Press, Oxford

Boyle AE, Harrison J (2013) Judicial settlement of international environmental disputes: current problems. J Int Dispute Settl 4:245-276

Bratspies RM, Miller RA (2006) Introduction. In: Bratspies RM, Miller RA (eds) Transboundary harm in international law: lessons from the Trail Smelter Arbitration. Cambridge University Press, Cambridge, pp 1-10

Brilmayer L (2007) From 'contract' to 'pledge': the structure of international human rights agreements. British Yearb Int Law 77:163-202

Brownlie I (1983) State responsibility: part 1. Clarendon Press, Oxford

Brus MMTA (2016) Het klimaatakkoord van Parijs: bouwen aan wereldrecht of bewijs van falende internationale samenwerking? [The Paris climate agreement: contribution to building world law or proof of failing international cooperation?]. Ars Aequi 65:615-623

Cançado Trindade AA (2015) Principle 15. In: Viñuales JE (ed) The Rio Declaration on Environment and Development: a commentary. Oxford University Press, Oxford, pp 403-428

Carozza PG (2003) Subsidiarity as a structural principle of international human rights law. Am J Int Law 97:38-79

Chinkin CM (2018) Human rights. In: Bowman MJ, Kritsiotis D (eds) Conceptual and contextual perspectives on the modern law of treaties. Cambridge University Press, Cambridge, pp 509-537

Coco A, de Souza Dias T (2020a) Part I: Due diligence and COVID-19: states' duties to prevent and halt the coronavirus outbreak. EJIL: Talk! (24 March 2020). https://www.ejiltalk.org/part-i-due-dilig ence-and-covid-19-states-duties-to-prevent-and-halt-the-coronavirus-outbreak/. Accessed 13 Aug 2020

Coco A, de Souza Dias T (2020b) Part II: Due diligence and COVID-19: states' duties to prevent and halt the coronavirus outbreak. EJIL: Talk! (25 March 2020). https://www.ejiltalk.org/part-ii-duediligence-and-covid-19-states-duties-to-prevent-and-halt-the-coronavirus-outbreak/. Accessed 3 Oct 2020 
Coco A, de Souza Dias T (2020c) Part III: Due diligence and COVID-19: states' duties to prevent and halt the coronavirus outbreak. EJIL: Talk! (25 March 2020). https://www.ejiltalk.org/part-iii-duediligence-and-covid-19-states-duties-to-prevent-and-halt-the-coronavirus-outbreak/. Accessed 24 Jan 2021

Craven M (2000) Legal differentiation and the concept of the human rights treaty in international law. Eur J Int Law 11:489-519

Crawford J (2013) State responsibility: the general part. Cambridge University Press, Cambridge

Dupuy PM (1999) Reviewing the difficulties of codification: on Ago's classification of obligations of means and obligations of result in relation to state responsibility. Eur J Int Law 10:371-385

Duvic-Paoli L-A (2018) The prevention principle in international environmental law. Cambridge University Press, Cambridge

Eagleton C (1928) The responsibility of states in international law. New York University Press, New York

Economides CP (2010) Content of the obligation: obligations of means and obligations of result. In: Crawford J, Pellet A, Olleson S (eds) The law of international responsibility. Oxford University Press, Oxford, pp 371-381

Ellis J (2006) Has international law outgrown Trail Smelter? In: Bratspies RM, Miller RA (eds) Transboundary harm in international law: lessons from the Trail Smelter Arbitration. Cambridge University Press, Cambridge, pp 56-65

Evrigenis D (1982) Recent case-law of the European Court of Human Rights on Articles 8 and 10 of the ECHR. Hum Rights Law J 3:121-139

Fitzmaurice M (2020) Due diligence in the use of international watercourses. In: Krieger H, Peters A, Kreuzer L (eds) Due diligence in the international legal order. Oxford University Press, Oxford, pp $129-146$

Foster CE (2010) Burden of proof in international courts and tribunals. Aust Yearb Int Law 29:27-86

French D (1998) 1997 Kyoto Protocol to the 1992 UN Framework Convention on Climate Change. J Environ Law 10:227-239

Gałuskina K (2017) Le standard juridique de bon père de famille et la symétrie entre les expressions bon père de famille et bonne mère de famille en droit français. Roczniki Humanistyczne 65:75-86

Gattini A (2014) Breach of international obligations. In: Nollkaemper A, Plakokefalos I (eds) Principles of shared responsibility in international law: an appraisal of the state of the art. Cambridge University Press, Cambridge, pp 25-59

Hakimi M (2010) State bystander responsibility. Eur J Int Law 21:341-385

Koivurova T (2010) Due diligence. Max Planck encyclopedia of public international law (February 2010). https://opil.ouplaw.com/view/10.1093/law:epil/9780199231690/law-9780199231690-e1034? prd=OPIL. Accessed 16 Mar 2021

Koningsveld H (2006) Het Verschijnsel Wetenschap [The Phenomenon of Science]. Uitgeverij Boom, Amsterdam

Kotzur M (2009) Good faith (Bona fide). Max Planck encyclopedia of public international law (January 2009). https://opil.ouplaw.com/view/10.1093/law:epil/9780199231690/law-9780199231690-e1412? prd=OPIL. Accessed 15 Dec 2020

Kratochvil J (2011) The inflation of the margin of appreciation by the European Court of Human Rights. Neth Q Hum Rights 29:324-357

Krieger H, Peters A (2020) Due diligence and structural change in the international legal order. In: Krieger H, Peters A, Kreuzer L (eds) Due diligence in the international legal order. Oxford University Press, Oxford, pp 351-390

Kulesza J (2016) Due diligence in international law. Brill Nijhoff, Boston

Longobardo M (2019) The relevance of the concept of due diligence for international humanitarian law. Wis Int Law J 37:44-87

Longobardo M (2020) Due diligence in international humanitarian law. In: Krieger H, Peters A, Kreuzer L (eds) Due diligence in the international legal order. Oxford University Press, Oxford, pp 183-199

Luca Burci G (2020) The outbreak of COVID-19 coronavirus: are the international health regulations fit for purpose? EJIL: Talk! (27 February 2020). https://www.ejiltalk.org/the-outbreak-of-covid-19coronavirus-are-the-international-health-regulations-fit-for-purpose/. Accessed 24 Jan 2021

Mace MJ (2016) Mitigation commitments under the Paris Agreement and the way forward. Climate Law $6: 21-39$

Mayer B (2018) Obligations of conduct in international law on climate change: a defence. Rev Eur Comp Int Environ Law 27:130-140 
McManus IC, Freegard M, Moore J, Rawles R (2010) Science in the making: right hand, left hand. II: the duck-rabbit figure. Laterality 15:166-185

Mégret F (2018) Nature of obligations. In: Moeckli D, Shah S, Sivakumaran S, Harris D (eds) International human rights law. Oxford University Press, Oxford, pp 86-109

Moons N (2018) The right to housing in law and society. Routledge, New York

Mowbray AR (2004) The development of positive obligations under the European Convention of Human Rights by the European Court of Human Rights. Hart Publishing, Hart

Nicolae I (2014) A comparative analysis regarding the obligation of result and the obligation of conduct (of means) in civil law. Bull Transilv Univ Braşov Ser VII Soc Sci Law 7:155-162

Papanicolopulu I (2020) Due diligence in the law of the sea. In: Krieger H, Peters A, Kreuzer L (eds) Due diligence in the international legal order. Oxford University Press, Oxford, pp 147-162

Parisi F (1994) Alterum non laedere: an intellectual history of civil liability. Am J Jurisprud 39:317-351

Peters A, Krieger H, Kreuzer L (2020) Due diligence in the international legal order: dissecting the leitmotif of current accountability debates. In: Peters A, Krieger H, Kreuzer L (eds) Due diligence in the international legal order. Oxford University Press, Oxford, pp 1-19

Pisillo-Mazzeschi R (1992) The due diligence rule and the nature of international responsibility of states. German Yearb Int Law 35:9-51

Rajamani L (2016) The 2015 Paris Agreement: interplay between hard, soft and non-obligations. J Environ Law 28:337-358

Rajamani L (2020) Due diligence in international climate change law. In: Krieger H, Peters A, Kreuzer $\mathrm{L}$ (eds) Due diligence in the international climate change law. Oxford University Press, Oxford, pp 163-180

Reuter P (1958) Droit international public. Presses universitaires de France, Paris

Sands P, Peel J, Fabra A, MacKenzie R (2018) Principles of international environmental law. Cambridge University Press, Cambridge

Sarkin J (2018) A methodology to ensure that states adequately apply due diligence standards and processes to significantly impact levels of violence against women around the world. Hum Rights Q 40:1-36

Schmitt MN (2015) In defense of due diligence in cyberspace. Yale Law J Forum 125:68-81

Schröder M (2014) Precautionary approach/principle. Max Planck encyclopedia of public international law (March 2014). https://opil.ouplaw.com/view/10.1093/law:epil/9780199231690/law-9780199231 690-e1603?prd=OPIL. Accessed 25 Aug 2020

Schwartz J-L, Grimault N, Hupé J-M et al (2012) Multistability in perception: binding sensory modalities, an overview. Philos Trans R Soc B Biol Sci 367:896-905

Shelton D, Gould A (2013) Positive and negative obligations. In: Shelton D (ed) The Oxford Handbook of international human rights law. Oxford University Press, Oxford, pp 563-584

Sicilianos L-A (2002) The classification of obligations and the multilateral dimension of the relations of international responsibility. Eur J Int Law 13:1127-1145

Simma B (2008) Reciprocity. Max Planck encyclopedia of public international law (April 2008). https:// opil.ouplaw.com/view/10.1093/law:epil/9780199231690/law-9780199231690-e1461?prd=OPIL. Accessed 19 Jan 2021

Simpson AWB (2003) Britain and the Genocide Convention. Br Yearb Int Law 73:5-64

Stoyanova V (2020) Due diligence versus positive obligations: critical reflections on the Council of Europe Convention on Violence against Women. In: Niemi J, Peroni L, Stoyanova V (eds) International law and violence against women: Europe and the Istanbul Convention. Routledge. https:// papers.ssrn.com/sol3/papers.cfm?abstract_id=3384607. Accessed 26 Mar 2021

Strasser KA (1996) Preventing pollution. Fordham Environ Law J 8:1-57

Toebes BC et al (2020) Toward human rights-consistent responses to health emergencies: what is the overlap between core right to health obligations and core international health regulation capacities? Health Hum Rights 22:99-112

Viñuales JE (2020) Due diligence in international environmental law: a fine-grained cartography. In: Krieger H, Peters A, Kreuzer L (eds) Due diligence in the international legal order. Oxford University Press, Oxford, pp 111-128

Violi F (2020) The function of the triad 'territory', 'jurisdiction' and 'control' in due diligence obligations. In: Krieger H, Peters A, Kreuzer L (eds) Due diligence in the international legal order. Oxford University Press, Oxford, pp 75-91

Voigt C (2016) The Paris Agreement: what is the standard of conduct for parties? Quest Int Law 26:17-18 
Westerman PC (2008) Normering via doelstelling: zorgplichten [Standardisation through objective: duties of care]. In: Westerman PC, Mackor AR (eds) Vormen van (de?)regulering [Forms of (de?) regulation]. Boom Juridische uitgevers, Den Haag, pp 51-72

Westerman PC (2013) Recht als raadsel: een inleiding in de rechtsfilosofie [Law as a riddle: an introduction to legal philosophy]. Uitgeverij Paris, Zutphen

Westerman PC (2018) Outsourcing the law: a philosophical perspective on regulation. Edward Elgar Publishing, Cheltenham

Winkler H (2017) Mitigation (Article 4). In: Klein D, Carazo MP, Doelle M et al (eds) The Paris Agreement on climate change: analysis and commentary. Oxford University Press, Oxford, pp 141-165

Wouters J (2007) Bronnen van het Internationaal Recht [Sources of international law]. In: Horbach N, Lefeber R, Ribbelink O (eds) Handboek internationaal recht [Handbook international law]. TMC Asser Press, The Hague, pp 81-122

Zimmerman R (1996) The law of obligations: Roman foundations of the civilian tradition. Oxford University Press, Oxford

Publisher's Note Springer Nature remains neutral with regard to jurisdictional claims in published maps and institutional affiliations. 